Western Washington University

Western CEDAR

$9-1998$

\title{
The Influence of Dispersal and Diet Breadth on Patterns of Genetic Isolation by Distance in Phytophagous Insects
}

Merrill A. Peterson

Western Washington University, merrill.peterson@wwu.edu

Follow this and additional works at: https://cedar.wwu.edu/biology_facpubs

Part of the Biology Commons

\section{Recommended Citation}

Peterson MA and Denno RF, 1998. The influence of dispersal and diet breadth on patterns of genetic isolation by distance in phytophagous insects. The American Naturalist 152:428-446

This Article is brought to you for free and open access by the Biology at Western CEDAR. It has been accepted for inclusion in Biology Faculty and Staff Publications by an authorized administrator of Western CEDAR. For more information, please contact westerncedar@wwu.edu. 


\section{The Influence of Dispersal and Diet Breadth on Patterns of Genetic Isolation by Distance in Phytophagous Insects}

Merrill A. Peterson* and Robert F. Denno†

Department of Entomology, University of Maryland, College Park, Maryland 20742

Submitted September 5, 1997; Accepted March 27, 1988

ABSTRACT: To determine the effects of dispersal ability and diet breadth on population-genetic structure, we reviewed the allozyme literature and estimated genetic isolation by distance (IBD) for 43 species/host races of phytophagous insects. Subsequently, we tested two opposing hypotheses regarding the influence of dispersal ability on IBD: that IBD slopes do not vary with mobility, but that intercepts increase with mobility, and, alternatively, that IBD slopes vary with dispersal ability. We found that from tens of kilometers to more than $1,000 \mathrm{~km}$, IBD is weak in sedentary and highly mobile species but pronounced in moderately mobile species. We attribute the weak IBD in strong dispersers to the homogenizing effects of gene flow, whereas in sedentary species, limited gene flow allows nearly all populations to diverge. In intermediate dispersers, genetic homogeneity is achieved at small spatial scales, but limited dispersal promotes genetic divergence over long distances. We also tested the hypothesis that IBD increases with decreasing diet breadth. We discovered no such pattern, casting doubt on the supposition that specialization promotes speciation by influencing population-genetic subdivision. Finally, we found that the number of populations is a more important consideration than the number of polymorphic loci in studies of IBD.

Keywords: dispersal, gene flow, specialization, phytophagous insects.

Gene flow among populations is widely considered to be an important factor influencing the evolution of both local adaptations and speciation (Mayr 1963; Endler 1977; Slatkin 1985). The ability of a population to adapt to unique local selective forces is determined not only by the strength of natural selection but also by the countering effects of genetic drift and especially gene flow (Slatkin 1973, 1987; Endler 1977). Indeed, theory sug-

* Present address: Biology Department, Western Washington University, Bellingham, Washington 98225; E-mail: peterson@biol.wwu.edu.

$\dagger$ E-mail: rd12@umail.umd.edu.

Am. Nat 1998. Vol. 152, pp. 428-446. (C) 1998 by The University of Chicago. 0003-0147/98/5203-0009\$03.00. All rights reserved. gests that gene flow from populations in which an alternate trait is at high frequency can prevent the evolution of local adaptations, even when selection favoring those adaptations is strong (Slatkin 1973, 1985; May et al. 1975). Therefore, several authors have argued that, for species in which gene flow occurs over limited distances, local adaptation may occur at a finer scale than in species with widespread gene flow (Slatkin 1973; Endler 1979; Hanks and Denno 1994; but see Mopper 1996). Similarly, it is typically argued that factors diminishing gene flow among populations should facilitate the process of speciation, since through their effect on gene flow, these factors should permit the divergence of populations (Mayr 1963; Bush 1975; Futuyma and Mayer 1980; Rice and Hostert 1993; Wiegmann et al. 1993).

A key to understanding the degree to which gene flow limits both the evolution of local adaptations and the formation of new species lies in understanding not only the amount of gene flow typically occurring among natural populations but also what factors govern levels of gene flow. The list of factors that have been hypothesized to influence gene flow is extensive and includes geographic distance (Wright 1943; Kimura and Weiss 1964; Maruyama 1971; Nagylaki 1976; Slatkin 1993; Hellberg 1994; Peterson and Denno 1998), dispersal capability (Waples 1987; Govindaraju 1988; Palumbi 1992; Williams and Guries 1994; Doherty et al. 1995; Shulman and Bermingham 1995; Peterson and Denno 1997, 1998), ecological specialization (Fryer 1959; Stanley 1979; Price 1980; Vrba 1984; Futuyma and Moreno 1988), phenological isolation (Wood and Guttman 1982; Schuster et al. 1989; Peterson 1995; Runyeon and Prentice 1996), habitat patchiness (Caccone and Sbordoni 1987; King 1987; McCauley 1991; Britten and Rust 1996; Roderick 1996; Young et al. 1996), habitat persistence (Roderick 1996; Peterson and Denno 1997, 1998), and the frequency and nature of extinction/recolonization events (Wade and McCauley 1988; Whitlock and McCauley 1990; Hastings and Harrison 1994).

The most common method for assessing the influence of ecological factors on gene flow has been to compare "indirect" gene flow estimates (sensu Slatkin 1985, 1987) 
for a small number of species (two to several) that differ in a key ecological trait (e.g., Zera 1981; Liebherr 1988; Williams and Guries 1994). A shortcoming of this approach is that the ecological differences among the species (e.g., dispersal differences) are likely to be confounded by a host of other species-specific differences that may also influence population-genetic structure. Thus, it is inappropriate to conclude that discrepancies in gene flow in the different species are due to their ecological differences. Several authors have overcome this problem by comparing species-specific gene flow estimates for a large number of species to determine if variation in gene flow parallels variation in an ecological trait (Eanes and Koehn 1978; Waples 1987; Govindaraju 1998; Peterson and Denno 1998). This approach has allowed the authors to more rigorously assess the influence of ecological traits by treating them as independent variables in statistical analyses. However, because there is little reason to think that gene flow among all populations of a species is equivalent, it is overly simplistic to assign a single gene flow estimate to each species. Thus, this type of analysis is also unsatisfying.

For many species, the most obvious source of intraspecific variation in gene flow is the decline in gene flow with geographic distance (Wright 1943). 'This decline, also known as genetic isolation by distance (hereafter IBD), is predicted for populations under equilibrium conditions. Under nonequilibrium conditions, the relationships among demes might be determined more by historical factors such as bottlenecks or range expansions than by the isolating effect of distance (Slatkin 1993). However, the fact that IBD has been demonstrated for a number of species (e.g., Slatkin 1993; Hellberg 1994; Britten et al. 1995; Peterson 1996; Peterson and Denno 1997) suggests that population-genetic variation is frequently at or nearly at equilibrium. Interestingly, IBD is known to vary among species, and even among groups of populations within a species (Slatkin 1993; Britten et al. 1995; Peterson and Denno 1997). Theoretically, it is possible for two species having the same species-specific gene flow estimate to have drastically different patterns of IBD. For example, one species might have high levels of gene flow over short distances, declining to low levels of gene flow at great distances. The second species might be characterized by moderate gene flow at all spatial scales. Averaged over the entire range of each species, gene flow in both species might appear to be similarly moderate, a similarity that would mask the striking IBD differences between the two. Thus, a thorough analysis of how ecological factors influence gene flow should provide an assessment of their influence on IBD, rather than on species-specific gene flow estimates.

To date, there has been no standardized method for assessing IBD. In some species, IBD is assessed using spa- tial autocorrelation statistics (e.g., Sokal et al. 1987; Stone and Sunnucks 1993), in others, genetic distances or identities are regressed against geographic distances (e.g., Phillips and Lanier 1985; Rosenberg 1989), and in others yet, population-genetic subdivision is estimated for groups of populations that are arranged hierarchically by the distances separating them (e.g., McCauley et al. 1988; Preziosi and Fairbairn 1992; Rank 1992; Costa and Ross 1994). However, none of these methods provide an explicit measure of the decline in gene flow (in units of $N_{\mathrm{e}} m$, where $m$ is the proportion of alleles in a population that arrive per generation from other populations) with each unit of distance. Recently, Slatkin (1993) proposed regressing log-transformed gene flow $\left(N_{\mathrm{e}} m\right)$ estimates against the log-transformed geographic distances separating populations, providing a method that is relatively independent of mutation and explicitly estimates the relationship between $N_{\mathrm{e}} m$ and geographic distance. This powerful and intuitively appealing analysis has been used to estimate IBD for several species (e.g., Hellberg 1994; Britten et al. 1995; Britten and Rust 1996; Peterson 1996; Peterson and Denno 1997), but too few to allow analyses of how IBD in these species might be influenced by ecological factors.

To determine the influence of ecological factors on genetic isolation by distance, we reviewed the literature for surveys of allozyme variation among populations of phytophagous insects. From the data in these surveys, we estimated the degree to which gene flow declines with distance, and then asked whether IBD in phytophagous insects is influenced by dispersal ability and/or diet breadth (an index of ecological specialization). Specifically, we tested two opposing hypotheses regarding the relationship between dispersal ability and the decline in gene flow with distance (IBD). The first hypothesis is that IBD slopes do not vary with dispersal ability but that IBD intercepts increase with increasing mobility. The second hypothesis is that IBD slopes do vary with dispersal ability. In addition, we tested the hypothesis that IBD decreases as diet breadth increases. In doing so, we tested the long-standing hypothesis that because suitable habitats are patchier for specialists than generalists, gene flow should be relatively less among populations of specialists (Fryer 1959; Stanley 1979; Price 1980; Vrba 1984; Futuyma and Moreno 1988).

We restricted our review to phytophagous insects because this group has been the subject of numerous population-genetic surveys (reviewed in Roderick 1996; Peterson and Denno 1998) and has played a central role in our understanding of both population-genetic structure and speciation (Ehrlich and Raven 1964; Bush 1975; Futuyma and Mayer 1980; Wood and Guttman 1982; Slatkin 1985; Mitter et al. 1988; Farrell and Mitter 1994; Roderick 1996; Peterson and Denno 1998). Furthermore, 
we limited the scope of this review to examining the effects of dispersal ability and ecological specialization because these ecological factors have been explicitly assessed for numerous phytophagous insect species. In contrast, phenological isolation, habitat patchiness, habitat persistence, and extinction/recolonization dynamics have been studied in too few species to allow analysis of their effects on IBD.

Our review is by far the most exhaustive compilation to date of IBD relationships for any group of organisms. Consequently, our analyses also allowed us to describe general patterns of IBD for a large and important group of organisms for the first time. In particular, we determined the proportion of insects that are characterized by a significant decline in gene flow with distance, the typical range of IBD slopes and intercepts shown by insects, and the degree of scatter in IBD relationships in insects. Furthermore, our study enables us to provide specific guidelines regarding both the number of populations and the number of polymorphic loci that should be included in future IBD studies.

\section{Material and Methods}

The Data Set

We surveyed the literature for studies of genetic variation in and among populations of phytophagous insects to determine the effects of dispersal ability and diet breadth on genetic isolation by distance. Because estimates of population-genetic structure from allozyme and DNA markers can differ considerably (Latorre et al. 1992; Haag et al. 1993; Mitton 1994; Baruffi et al. 1995), and because published studies of allozyme variation far outnumber studies using DNA markers, we restricted our survey to allozyme studies. It remains unclear whether allozymeor DNA-based estimates of gene flow are more accurate, since the differences between the methods can be attributed to a variety of factors. DNA markers may be better able to detect subtle subdivision among populations because of their resolution of finer genetic differences (Mitton 1994). Furthermore, it is known that the geographic structure of some allozyme loci can be influenced by selection (Watt et al. 1983, 1985; Anderson and Oakeshott 1984; Begun and Aquadro 1994). The degree to which selection influences DNA-based markers is less wellknown. There are also reasons to believe that measures of population structure based on mtDNA, the marker of choice for the vast majority of published DNA-based studies of the population-genetic structure of insects, are not representative of the genome. In particular, mtDNA is typically maternally inherited, and so it fails to reveal male-mediated gene flow (Avise et al. 1987; Palumbi and Baker 1994; Roderick 1996). Furthermore, because mtDNA is haploid, it has a smaller effective population size than diploid markers and is thus more sensitive to genetic drift (Wilson et al. 1985; Roderick 1996). Finally, estimates of population structure from mtDNA variation are single-locus estimates and may therefore be more biased than estimates involving multiple loci (Mitton 1994; Roderick 1996).

We restricted our review to nonsocial, sexually reproducing phytophagous insects in order to minimize variation in isolation by distance due to social structure and/ or mode of reproduction. In this review, we estimated IBD from data in 53 studies of allozyme variation in and among phytophagous insect populations. These studies represented 43 species/host races of phytophagous insects occurring in 19 families in six orders. In those cases in which allozyme variation was assessed within and among host races (Pashley et al. 1985; Feder and Bush 1989; Guttman and Weigt 1989; Feder et al. 1990; McPheron 1990; Waring et al. 1990), we only examined IBD within host races. For a study to be included in our review, it had to include at least seven populations of a species or host race, with at least $200 \mathrm{~km}$ separating the most widely separated populations that were sampled, and no more than $200 \mathrm{~km}$ separating the most closely situated populations. Furthermore, the range of distances separating sampled populations (maximum distance minus minimum distance) had to span at least $150 \mathrm{~km}$ to allow us to assess isolation by distance over at least $150 \mathrm{~km}$. The reasoning behind this criterion was that because IBD relationships typically have a lot of scatter (Slatkin 1993; Hellberg 1994; Britten et al. 1995; Peterson 1996; Peterson and Denno 1997), it may only be possible to detect significant IBD if a sufficiently broad geographic scale has been surveyed. Studies included in our survey employed at least two polymorphic loci (a locus was considered polymorphic if the frequency of the commonest allele did not exceed 0.95 in all sampled populations). We did not include studies of introduced or recently colonized populations. In those instances in which both native and introduced populations were sampled, we assessed isolation by distance for the native populations only, providing the set of native populations met the above criteria.

With few exceptions (Britten et al. 1995; Peterson 1996; Peterson and Denno 1997), an estimate of isolation by distance was not provided by the authors, so we obtained such an estimate using data on allele frequencies and distances separating populations. Thus, to be included in our review, studies that did not provide an estimate of isolation by distance had to provide allele frequencies and enough information on the locations of populations to allow us to estimate the straight-line geographic distances separating all pairwise combinations of populations. It is important to note that, in our analyses, we were forced to exclude data from some loci (if they 
were not scored for all populations) or some populations (if they were not surveyed for all allozyme loci) for certain data sets. We made these omissions in a manner to minimize the loss of data. In one instance (Harvey 1996), we were unable to determine the location of a single population, so we excluded this population from our analyses. Because this review compares studies conducted by different authors who certainly conducted allozyme surveys for different purposes, the data sets vary in the number of populations surveyed, the number of allozyme loci used, the number of individuals sampled per population, and the spatial distribution of samples. This variation would be expected to add noise to any relationship between IBD and dispersal/diet breadth, diminishing to some extent the likelihood of detecting significant relationships.

\section{Estimating Isolation by Distance}

To estimate isolation-by-distance relationships from the data in these studies, we used Slatkin's (1993) " $\hat{\mathrm{M}}$ " program to obtain gene flow estimates among all pairwise combinations of populations in a study. This program calculates the genetic subdivision of all pairs of populations using both Weir and Cockerham's (1984) $\theta$ and Nei's (1973) $G_{S T}$. Both statistics provide an estimate of Wright's $(1951) F_{S T}$, which is related to gene flow $\left(N_{\mathrm{e}} m\right)$ by the equation $F_{S T}=1 /\left(4 N_{\mathrm{e}} m+1\right)$. Subsequently, Slatkin's " $\hat{M}$ " program uses these values of $\theta$ and $G_{S T}$ to estimate gene flow among all pairwise combinations of populations. Because values of $\theta$ among some pairs of populations were negative, yielding nonsensical negative estimates of gene flow, we only report here the analyses based on Nei's (1973) $G_{S T}$.

To determine the relationship between gene flow and geographic distance, we conducted Mantel's (1967) randomization test for each data set (Manly 1991). We used this test instead of ordinary least squares (OLS) regression since not all data points were independent. Both $N_{e} m$ and geographic distances were log-transformed for these analyses, following Slatkin (1993). For the Mantel's tests, we used the program RT, version 1.04 (Manly 1992), performing 1,000 randomizations for each analysis. These tests provided estimates of the slope and intercept of the IBD relationship, as well as an estimate of the statistical significance of that relationship. To estimate the scatter in these relationships, we also used OLS regression, determining the correlation coefficient for each IBD relationship.

\section{Categorizing Dispersal Ability and Diet Breadth}

We assigned each species to a category of dispersal ability (sedentary, moderately mobile, and highly mobile) based on published accounts of per generation estimates of the movement of marked individuals (most cases); rates of invasion into new regions; and the appearance of individuals outside of breeding grounds (following Peterson and Denno 1998). Each of these methods of estimating dispersal is potentially biased (see discussion in Peterson and Denno 1998), but we feel confideñt that our assignment of species to different dispersal categories is a fair representation of true dispersal differences among those species. Species that are capable of dispersing up to $1 \mathrm{~km}$ over the course of a single generation were categorized as sedentary, species that can disperse between $1 \mathrm{~km}$ and 20 $\mathrm{km}$ were categorized as moderately mobile, and species known to disperse distances exceeding $20 \mathrm{~km}$ were categorized as highly mobile. Dispersal information was not available for 12 of the 43 species/host races (28\%) in our review (table 1), so these species were excluded from the analyses of the effects of dispersal on IBD.

We also categorized species by diet breadth using published accounts of diet breadth. For our review, "monophagous" species feed exclusively on plants in a single genus, "oligophagous" species feed on plants in more than one genus in a single family, and "polyphagous" species feed on plants in multiple families. We were able to assign each species/race to a category of diet breadth.

\section{Analyses}

To assess the incidence of IBD in phytophagous insects, we determined the proportion of the studies in our review that revealed statistically significant IBD. We also graphically assessed each study to determine how many of the significantly negative IBD relationships might be attributable to vicariance, rather than true isolation by distance (sensu Wright 1943). Vicariance could serve as an alternative explanation for a significant pattern of IBD if that pattern were driven entirely by one or a few populations that were geographical outliers. To determine if there were differences among the major insect orders in the slopes and intercepts of the IBD relationships, we performed two separate ANOVAs, one for the analysis of slopes and the other for the analysis of intercepts. For each ANOVA, we treated species/host races as independent data points, nested within order. Thus, in those cases in which a species/host race was represented by more than one study, we determined an average slope and intercept for that species/host race. We adopted this same procedure for all analyses in which we treated species/host races as independent.

To determine whether statistically significant IBD is detected more frequently in studies that include a large number of populations, we regressed the angular-transformed $P$ values of all 53 studies against the number of populations sampled in each. Similarly, we regressed 
Table 1: Isolation by distance relationships in phytophagous insects, based on published allozyme surveys

\begin{tabular}{|c|c|c|c|c|c|c|c|c|c|c|c|}
\hline Order, family, and species & $\begin{array}{c}\text { No. of } \\
\text { populations }\end{array}$ & $\begin{array}{l}\text { Distance } \\
\text { range } \\
(\mathrm{km})\end{array}$ & $\begin{array}{l}\text { Poly } \\
\text { loci }\end{array}$ & $\begin{array}{c}\text { Diet } \\
\text { breadth }\end{array}$ & $\begin{array}{l}\text { Dispersal } \\
\text { ability }\end{array}$ & $\begin{array}{l}I B D \\
\text { slope }\end{array}$ & $\begin{array}{c}I B D \\
\text { intercept }\end{array}$ & $r^{2}$ & $\mathbf{P}$ & Source for $I B D$ & Additional sources \\
\hline \multicolumn{12}{|l|}{$\begin{array}{l}\text { Orthoptera: } \\
\text { Acrididae: } \\
\text { Chorthippus brunneus }\end{array}$} \\
\hline Chorthippus brunneus & 10 & $1-200$ & 3 & Oligo & Sedentary & .054 & 1.607 & .020 & .381 & Gill 1981 & $\begin{array}{l}\text { R. Chapman, personal commu- } \\
\text { nication:* Richards and } \\
\text { Waloff } 1954^{\dagger}\end{array}$ \\
\hline $\begin{array}{l}\text { Melanoplus sangumipes } \\
\text { Tettigoniudae: }\end{array}$ & 9 & $20-410$ & 3 & Poly & $\begin{array}{l}\text { Highly } \\
\text { mobile }\end{array}$ & -.160 & 1.868 & .020 & 437 & $\begin{array}{l}\text { Chapko and Bidochka } \\
1986\end{array}$ & $\begin{array}{l}\text { Mulkern et al. 1969;* Johnson } \\
1969+\end{array}$ \\
\hline $\begin{array}{l}\text { Ephippiger ephuppiger } \\
\text { Hemiptera: } \\
\text { Membracidae: } \\
\text { Enchenopa "binotata": }\end{array}$ & & & Oudman et al. 1990 & Duijm and Oudman $1983^{*}$ \\
\hline Juglans race & 10 & $7-1,090$ & 8 & Mono & Sedentary & -.420 & 1.247 & .163 & .022 & $\begin{array}{l}\text { Guttman and Weigt } \\
1989\end{array}$ & . \\
\hline \multicolumn{11}{|l|}{$\begin{array}{l}\text { Delphacidae: } \\
\text { Prokelisia dolus: } \\
\text { Atiantic coast }\end{array}$} & \\
\hline Atlantic coast & 16 & $80-2,350$ & 6 & Mono & $\cdots$ & $-.231 \ddagger$ & $2.011 \ddagger$ & $.050 \ddagger$ & $.018 \ddagger$ & $\begin{array}{l}\text { Peterson and Denno } \\
1997\end{array}$ & .. \\
\hline Gulf coast & 11 & $135-1,940$ & 6 & Muno & . & $.444 \ddagger$ & $2.528 \ddagger$ & $.140 \ddagger$ & $.008 \ddagger$ & $\begin{array}{l}\text { Peterson and Denno } \\
1997\end{array}$ & \\
\hline $\begin{array}{l}\text { Mean } \\
\text { Prokeltsia marginata: }\end{array}$ & $\cdot$ & $\cdots$ & $\cdots$ & Mono & $\cdot \cdot$ & -.338 & 2.270 & $\cdots$ & $\cdots$ & $\cdot \cdot$ & Snoule tonct \\
\hline Atlantic coast & 12 & $80-1,800$ & 7 & Mono & $\begin{array}{l}\text { Highly } \\
\text { mobile }\end{array}$ & -.035 & 1.599 & .000 & $.570 \ddagger$ & $\begin{array}{l}\text { Peterson and Denno } \\
1997\end{array}$ & Sparks et al. $1986 \dagger$ \\
\hline Gulf coast & 11 & $135-1,940$ & 7 & Mono & $\begin{array}{l}\text { Highly } \\
\text { mobile }\end{array}$ & -.066 & 1.513 & .000 & $.470 \ddagger$ & $\begin{array}{l}\text { Petersos and Denno } \\
1997\end{array}$ & Sparks et al. $1986 \dagger$ \\
\hline $\begin{array}{l}\text { Mean } \\
\text { Aphididae: }\end{array}$ & & $\cdots$ & $\cdots$ & Monn & $\begin{array}{l}\text { Highly } \\
\text { mobile }\end{array}$ & -.051 & 1.556 & $\cdots$ & $\cdots$ & & $\cdots$ \\
\hline $\begin{array}{l}\text { Rhopalosiphum padis } \\
\text { Coleoptera: } \\
\text { Chrysomelidae: }\end{array}$ & 8 & $6-520$ & 2 & Poly & $\begin{array}{l}\text { Highly } \\
\text { mobile }\end{array}$ & -.282 & 1.719 & .274 & .020 & $\begin{array}{l}\text { Loxdale and Brookes } \\
1988\end{array}$ & . \\
\hline \multicolumn{12}{|l|}{$\begin{array}{l}\text { Chrysomelidae: } \\
\text { Chrysoltna aurichalceat }\end{array}$} \\
\hline Chrysolina aurichalceat & 9 & $25-1,945$ & 5 & Oligo & Sedentary & -.197 & 1.026 & .023 & .438 & $\begin{array}{l}\text { Sakanoue and Fujiyama } \\
1987\end{array}$ & Suzukı 1978† \\
\hline $\begin{array}{l}\text { Diabrotica barberi } \\
\text { Curculionidae: }\end{array}$ & 15 & $80-1,905$ & 6 & Oligo & $\begin{array}{l}\text { Moderately } \\
\text { mobile }\end{array}$ & .927 & \multicolumn{3}{|c|}{$\begin{array}{l}\text { Curculionidae: } \\
\text { Pissodes strobi }\end{array}$} & McDonald et al. 1985 & Haddock 1984† \\
\hline $\begin{array}{l}\text { Pissodes strobi } \\
\text { Scolytidae: }\end{array}$ & 17 & $190-3,620$ & 9 & Oligo & $\begin{array}{l}\text { Moderately } \\
\text { mobile }\end{array}$ & -.202 & 1.333 & .034 & .003 & $\begin{array}{l}\text { Phillips and Lanier } \\
1985\end{array}$ & $\begin{array}{l}\text { McMullen and Condrashoff } \\
1973 \dagger\end{array}$ \\
\hline $\begin{array}{l}\text { Dendroctonus ponderosae } \\
\text { D. ponderosae }\end{array}$ & 8 & $10-370$ & 6 & Mono & $\cdots$ & .015 & 1.151 & .000 & $\begin{array}{l}.950 \\
.045\end{array}$ & $\begin{array}{l}\text { Higby and Stock } 1982 \\
\text { Stock et al. } 1984\end{array}$ & $\because$ \\
\hline $\begin{array}{l}D . \text { ponderosae } \\
\text { Mean } D . \text { ponderosae }\end{array}$ & 12 & $\begin{array}{l}55-1,460 \\
\quad\end{array}$ & $\begin{array}{l}6 \\
\cdots\end{array}$ & $\begin{array}{l}\text { Muno } \\
\text { Mono }\end{array}$ & $\cdot$ & $\begin{array}{r}.396 \\
-.191\end{array}$ & $\begin{array}{l}2.326 \\
1.739\end{array}$ & $\begin{array}{l}.147 \\
\cdots\end{array}$ & .045 & & $\because$ \\
\hline \multicolumn{12}{|l|}{$\begin{array}{l}\text { Iepidoptera: } \\
\text { Pyralidae: } \\
\quad \text { Homensoma electellum }\end{array}$} \\
\hline $\begin{array}{l}\text { Homeosoma electellum } \\
\text { Olethreutidae: }\end{array}$ & 16 & $75-2,840$ & 2 & Poly & $\begin{array}{l}\text { Highly } \\
\text { mobike }\end{array}$ & .191 & .746 & .010 & .420 & $\begin{array}{l}\text { Beregovoy and Gill } \\
1986\end{array}$ & Teetes and Randolph 1969* \\
\hline $\begin{array}{l}\text { Rhyacionia frustrana } \\
\text { Tortricidae: }\end{array}$ & 7 & $1.7-3,600$ & 5 & Mono & - & .049 & 1.313 & .013 & .758 & Namkoong et al 1982 & $\cdots$ \\
\hline Choristoneura fumterana & 7 & $6.5-225$ & 3 & Oligo & $\begin{array}{l}\text { Highly } \\
\text { mobile }\end{array}$ & .013 & 1.549 & .000 & .931 & May et al. 1977 & Covell $1984^{*}$ \\
\hline C. fumiferanal & 10 & $90-4,135$ & 6 & Oligo & $\begin{array}{l}\text { Highly } \\
\text { mobile }\end{array}$ & -.200 & 1.783 & .086 & .045 & Harvey 1996 & Covell $1984^{*}$ \\
\hline Mean C. fumiferana & $\cdots$ & $\cdot \cdot$ & & Oligo & $\begin{array}{l}\text { Highly } \\
\text { mobile }\end{array}$ & -.094 & 1.666 & . & $\cdots$ & Willhite ord Sro & \\
\hline $\begin{array}{l}\text { Choristoneura occidentalis } \\
\text { Ctenopseustis "obliquena": }\end{array}$ & 13 & 20. 440 & 13 & Oligo & $\cdots$ & -176 & 1.197 & 020 & .203 & $\begin{array}{l}\text { Willhite and Stock } \\
1983\end{array}$ & Covell $1984^{*}$ \\
\hline Type I, III & 10 & $10 \quad 1,275$ & 16 & Poly & $\cdots$ & -.388 & 2.353 & .164 & .003 & $\begin{array}{l}\text { White and Lambert } \\
1995\end{array}$ & White and Lambert 1994* \\
\hline $\begin{array}{l}\text { Type II } \\
\text { Planotortrix "excessana": }\end{array}$ & 8 & $10-1,310$ & 13 & Poly & & .724 & 3.150 & .456 & .010 & $\begin{array}{l}\text { White and Lambert } \\
1995\end{array}$ & White and Lambert $1994^{*}$ \\
\hline Type A & 10 & $55-1,250$ & 13 & Poly & - & -1.176 & 4.552 & .506 & 003 & $\begin{array}{l}\text { White and Lambert } \\
1995\end{array}$ & White and Lambert 1994* \\
\hline $\begin{array}{l}\text { Type B + C } \\
\text { Noctuidae: }\end{array}$ & 10 & $35 \cdot 1,181$ & 11 & Poly & $\cdots$ & -.142 & 1.950 & .017 & .402 & $\begin{array}{l}\text { White and Lambert } \\
1995\end{array}$ & White and Lambert 1994* \\
\hline Helicoverpa armigeral & 8 & $25 \quad 2,795$ & 5 & Poly & $\begin{array}{l}\text { Highly } \\
\text { mobile }\end{array}$ & -.376 & 2.473 & 287 & .118 & Daly and Gregg 1985 & \\
\hline Helicoverpa virescens' & 9 & $135-3,290$ & 10 & Poly & $\begin{array}{l}\text { Highly } \\
\text { mobile }\end{array}$ & .048 & .702 & .006 & .693 & Sluss and Graham 1979 & Covell 1984* \\
\hline Spodoptera exempta & 15 & $13-2,350$ & 3 & Oligo & $\begin{array}{l}\text { Highly } \\
\text { mobile }\end{array}$ & .106 & 1.729 & .024 & .396 & den Boer 1978 & Rainey $1979 \dagger$ \\
\hline $\begin{array}{l}\text { Spodoptera frugiperda, corn race } \\
\text { Lycaenidae: }\end{array}$ & 8 & $145-3,305$ & 9 & Poly & $\begin{array}{l}\text { Highly } \\
\text { mobile }\end{array}$ & -.102 & 1.581 & .007 & .628 & Pashley et al. 1985 & Covell 1984* \\
\hline Euphlotes enoptes & 18 & $.7-405$ & 6 & Mono & $\begin{array}{l}\text { Moderately } \\
\text { mobile }\end{array}$ & $-.252 \ddagger$ & $1.593 \ddagger$ & $.336 \ddagger$ & .001 & Peterson 1996 & Peterson $1997^{+}$ \\
\hline
\end{tabular}




\begin{tabular}{|c|c|c|c|c|c|c|c|c|c|c|c|}
\hline Order, family, and species & $\begin{array}{c}\text { No. of } \\
\text { populations }\end{array}$ & $\begin{array}{c}\text { Distance } \\
\text { range } \\
(\mathrm{km})\end{array}$ & $\begin{array}{l}\text { Poly } \\
\text { loci }\end{array}$ & $\begin{array}{c}\text { Diet } \\
\text { breadth }\end{array}$ & $\begin{array}{l}\text { Dispersal } \\
\text { ability }\end{array}$ & $\begin{array}{l}\text { IBD } \\
\text { slope }\end{array}$ & $\begin{array}{c}\text { IBD } \\
\text { intercept }\end{array}$ & $\mathbf{r}^{2}$ & $P$ & Source for $I B D$ & Additional sources \\
\hline \multicolumn{12}{|l|}{ Pieridae: } \\
\hline Pteris (napt) marginalss & 21 & $30-1,955$ & 12 & Oligo & $\begin{array}{l}\text { Moderately } \\
\text { mobile }\end{array}$ & -.978 & 2.843 & .640 & .001 & $\begin{array}{l}\text { Geiger and Shapiro } \\
1992\end{array}$ & Chew $1981^{+}$ \\
\hline Pontia protodice & 7 & $40-4,000$ & 4 & Poly & $\begin{array}{l}\text { Highly } \\
\text { mobile }\end{array}$ & -.099 & 1336 & .041 & 540 & $\begin{array}{l}\text { Shapiro and (reiger } \\
1985\end{array}$ & Scott 1986; ' Shapiro $1982 \dagger$ \\
\hline \multicolumn{12}{|l|}{ Papilıonidae: } \\
\hline Papilio glaucus glaucus & 8 & $65-790$ & 12 & Poly & $\begin{array}{l}\text { Moderately } \\
\text { mobile }\end{array}$ & -.101 & 1374 & .018 & 732 & Hagen 1990 & Scott $1986^{*}$ \\
\hline Papilio zeltcaon & 10 & $30-1,035$ & 3 & Poly & $\begin{array}{l}\text { Moderately } \\
\text { mobile }\end{array}$ & .030 & .604 & .001 & .924 & Tong and Shapiro 1989 & Shields $1967 \dagger$ \\
\hline Parnassius mnemosyne & 24 & $7-465$ & 9 & Mono & Sedentary & -.432 & 1.379 & .177 & .002 & $\begin{array}{l}\text { Napolitano and Desci- } \\
\text { mon } 1994\end{array}$ & Napolitano et al. $1988^{+}$ \\
\hline \multicolumn{12}{|l|}{ Nymphalıdae: } \\
\hline Boloria improbal & 8 & $40-3,350$ & 12 & Mono & Sedentary & -.417 & 986 & .161 & .014 & $\begin{array}{l}\text { Britten and Brussard } \\
1992\end{array}$ & $\cdots$ \\
\hline Coenonympha tullia & 21 & 2.650 & 11 & Oligo & $\begin{array}{l}\text { Moderately } \\
\text { mobile }\end{array}$ & .198 & 1.262 & .079 & .013 & Porter and Geiger 1988 & Scutt 1986; Shapiro 1974 $\dagger$ \\
\hline C. tullia & 9 & $20-1,050$ & 6 & Oligo & $\begin{array}{l}\text { Moderately } \\
\text { mobile }\end{array}$ & -.992 & 3.399 & .289 & .003 & Wiernasz 1989 & Scott $1986 ;{ }^{*}$ Shapiro $1974 \dagger$ \\
\hline Mean C. tullia & $\cdots$ & $\cdots$ & $\cdot \cdot$ & Oligo & $\begin{array}{l}\text { Moderately } \\
\text { mobile }\end{array}$ & -.595 & 2.331 & & 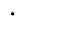 & & $\cdot$ \\
\hline Euphydryas thalcedona & 10 & $20-575$ & 7 & Poly & $\begin{array}{l}\text { Moderately } \\
\text { mobile }\end{array}$ & .586 & 2.299 & .211 & .057 & McKechnie et al. 1975 & $\begin{array}{l}\text { Scott 1986* Brown and Fhrlich } \\
\text { 1980† }\end{array}$ \\
\hline Euphydryas editha & 21 & $10-1,215$ & 8 & Poly & $\begin{array}{l}\text { Moderately } \\
\text { mobile }\end{array}$ & -.605 & 2.026 & .326 & .001 & McKechnie et al. 1975 & $\begin{array}{l}\text { Radtkey and Singer 1995; }{ }^{*} \text { Har- } \\
\text { rison } 1989 \dagger\end{array}$ \\
\hline Central Rocky Mountains & 7 & 4. 400 & $\cdots$ & Mono & $\begin{array}{l}\text { Moderately } \\
\text { mobile }\end{array}$ & $-.452 \ddagger$ & $1.984 \ddagger$ & $.587 \ddagger$ & $.0005 \ddagger$ & Britten et al. 1995 & $\begin{array}{l}\text { Holdren and Ehrlich 1982; } \\
\text { Harrison } 1989 \dagger\end{array}$ \\
\hline Great Basin & 11 & $12-500$ & & Oligo & $\begin{array}{l}\text { Moderately } \\
\text { mobile }\end{array}$ & $-.161 \ddagger$ & $1.028 \ddagger$ & $.051 \ddagger$ & $.120 \ddagger$ & Britten et al. 1995 & $\begin{array}{l}\text { Murphy and Ehrlich 1983;* } \\
\text { Harrison } 1989 \dagger\end{array}$ \\
\hline Mean & $\cdots$ & $\cdot \cdot$ & $\cdots$ & $\cdots$ & $\begin{array}{l}\text { Moderately } \\
\text { mobile }\end{array}$ & -.406 & 1.679 & & & ? & $\cdot$ \\
\hline L.menitis lorquini (sensu strictu) & 7 & $6 \cdot 465$ & 6 & Poly & $\begin{array}{l}\text { Moderately } \\
\text { mobile }\end{array}$ & .267 & 1.687 & .100 & .121 & Porter 1990 & Scott $1986^{*}$ \\
\hline Speyera nokomst" & 13 & $20-450$ & 4 & Mono & $\cdot$ & -.440 & 1.514 & .062 & .083 & Britten et al. 1994 & $\cdot$ \\
\hline \multicolumn{12}{|l|}{ Diptera. } \\
\hline \multicolumn{12}{|l|}{ Agromyzidae: } \\
\hline $\begin{array}{l}\text { Phytomyza chaerophyllit } \\
\text { Tephritidac: }\end{array}$ & \multicolumn{11}{|c|}{ Tephritidac: } \\
\hline $\begin{array}{l}\text { Eurosta "solidaginis," Solidago } \\
\text { altissima } \\
\text { race }\end{array}$ & 9 & $1-1,785$ & 5 & Mono & $\cdot$ & -.088 & 1.035 & .016 & .641 & Waring et al. 1990 & • \\
\hline Rhagoletis completa & 7 & $95-1,320$ & 4 & Mono & $\begin{array}{l}\text { Highly } \\
\text { mobile }\end{array}$ & -135 & 1.862 & .046 & .308 & Berlocher 1984 & $\cdot$ \\
\hline $\begin{array}{l}\text { Rhagoletts mendax, Vaccinum } \\
\text { samples only } \\
\text { Rhagoletis "pomonella": }\end{array}$ & 15 & $35-1,470$ & 11 & Oligo & $\cdots$ & -.068 & 1.356 & .010 & .385 & Berlocher 1995 & \\
\hline Crataegus racel & 33 & {$[2-263$} & 6 & Mono & $\begin{array}{l}\text { Moderately } \\
\text { mobile }\end{array}$ & -.575 & 2.074 & .142 & .001 & Feder and Bush 1989 & Maxwell and Parsons $1968 t$ \\
\hline Crataegus racel & 10 & $45-1,390$ & 6 & Mono & $\begin{array}{l}\text { Moderately } \\
\text { mobile }\end{array}$ & -.442 & 2.163 & .074 & .084 & Feder et al. 1990 & Maxwell and Parsons $1968 \dagger$ \\
\hline Crataegus race & 13 & $135 \cdot 4,165$ & 10 & Mono & $\begin{array}{l}\text { Moderately } \\
\text { mobile }\end{array}$ & -.560 & 2.526 & .236 & .001 & McPheron 1990 & Maxwell and Parsons $1968 \dagger$ \\
\hline Mean, Crataegus race & $\cdots$ & & & Mono & $\begin{array}{l}\text { Moderately } \\
\text { mobile }\end{array}$ & -.526 & 2.254 & $\cdots$ & $\cdots$ & $\cdots$ & $\cdot \cdot \cdot$ \\
\hline Malus racel & 29 & $12-263$ & 6 & Mono & $\begin{array}{l}\text { Moderately } \\
\text { mobile }\end{array}$ & -.172 & 1.668 & .026 & .076 & Feder and Bush 1989 & Maxwell and Parsons $1968 \dagger$ \\
\hline Malus racel & 11 & $45-2,090$ & 6 & Mono & $\begin{array}{l}\text { Moderately } \\
\text { mobile }\end{array}$ & .418 & 2.382 & .270 & .010 & Feder et al. 1990 & Maxwell and Parsons 1968† \\
\hline Mean, Malus race & $\cdots$ & & $\cdot$ & Mono & $\begin{array}{l}\text { Moderately } \\
\text { mobile }\end{array}$ & -.295 & 2.025 & $\cdots$ & $\cdots$ & $\cdots$ & $\cdot$ \\
\hline \multicolumn{12}{|l|}{$\begin{array}{l}\text { Hymenoptera. } \\
\text { Cynipidae: }\end{array}$} \\
\hline Androcus quercuscalicts & 11 & $25-840$ & 7 & Mono & $\begin{array}{l}\text { Highly } \\
\text { mobile }\end{array}$ & -.353 & 1.987 & .190 & .047 & $\begin{array}{l}\text { Stone and Sunnucks } \\
1993\end{array}$ & \\
\hline
\end{tabular}

Note: For each species, the following data are listed: the number of populations sampled, the range of distances separating sampled populations, the number of polymorphic loci surveyed, diet breadth (monophagous, oligophagous, polyphagous), dispersal ability (sedentary, moderately mobile, highly mobile), slope of the IBD relationship, intercept of the IBD relationship, correlation coefficient $\left(r^{2}\right)$, and the significance of the IBD relationship $(P)$. See "Material and Methods" for procedures for estimating IBD parameters and statistics as well as criteria for assigning species to categories of diet breadth and dispersal ability. For each species, the source for the IBD relationship and additional sources (if needed) for ecological data are listed.

* Source for host range.

$\dagger$ Source for dispersal ability.

\$ These IBD parameters/statistıcs were taken directly from the article listed in the column labeled "Source for IBD." All other IBD parameters/ statistics are based on our reanalysis of data that were published in that article.

$\$ 1985$ data only.

"IBD estimate based on part of data set-that is, some loci/populations were excluded from analysis. See "Material and Methods" for criteria for exclusion. 
angular-transformed $P$ values against the number of polymorphic loci in each study to test the hypothesis that the significance of IBD relationships increases with the number of loci surveyed.

We tested two opposing hypotheses regarding the relationship between IBD and dispersal ability. The first hypothesis, which follows the results of simulations by Slatkin and Maddison (1990), is that IBD slopes do not vary with dispersal ability but that IBD intercepts increase with increasing dispersal ability (fig. 1A). Slatkin and Maddison (1990) found that IBD slopes were approximately equal across three levels of dispersal ability, but an explanation for this result was not provided. In addition, they showed that IBD intercepts in simulation studies approximate Wright's (1946) neighborhood size, or the number of individuals in an area of panmixis. It is logical that highly mobile species should have greater neighborhood sizes, and thus IBD intercepts, than sedentary species, since the area of panmixis should be greater for the more vagile species.

The second hypothesis is that IBD slopes vary with dispersal ability, whether or not intercepts increase with increasing mobility (fig. $1 B, C$ ). In particular, we hypothesized that over very small spatial scales, IBD is very steep in the most sedentary species, such that gene flow declines to negligible levels over a short distance. Beyond this distance, further IBD is weak or absent for two reasons. First, beyond this distance, all populations are free to diverge through genetic drift. More important, with a finite number of alleles, there are limitations to the degree to which populations can become differentiated. This is particularly true when the number of populations sampled exceeds the number of alleles per locus (as is the case for most allozyme studies), since in this situation, it is impossible for each population to become fixed for a unique allele. In the most mobile species, the decline in gene flow over a large spatial scale is weak, due to the homogenizing effects of gene flow. It is possible for gene flow to decline to very low levels in these vagile species, but this is only expected to occur over extremely large distances. We hypothesized that species of intermediate dispersal ability would exhibit intermediate levels of IBD and that gene flow in these species would attenuate to very low levels at a distance between that for sedentary and highly mobile species.

Under this model of the relationship between IBD and dispersal, the rank order of IBD slopes should vary with spatial scale. At the smallest spatial scale ( $I$ in fig. $1 B, C$ ), the steepness of IBD slopes should decrease with increasing mobility. At an intermediate spatial scale ( $I I$ in fig. $1 B, C)$, species of moderate mobility should exhibit the steepest IBD slopes, and at very large spatial scales (III in fig. $1 B, C$ ), the steepest slopes should be represented by
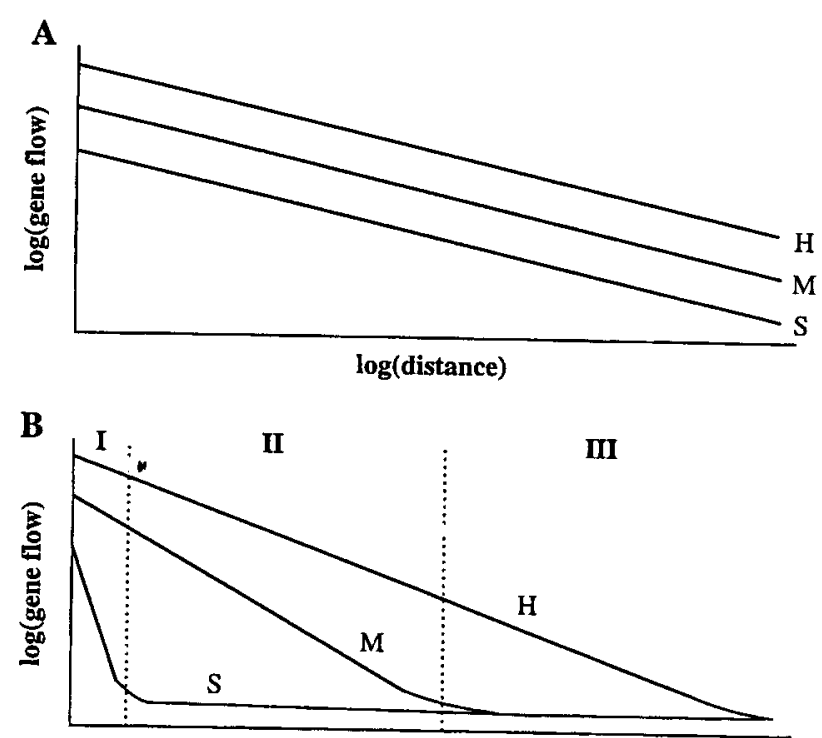

$\log$ (distance)

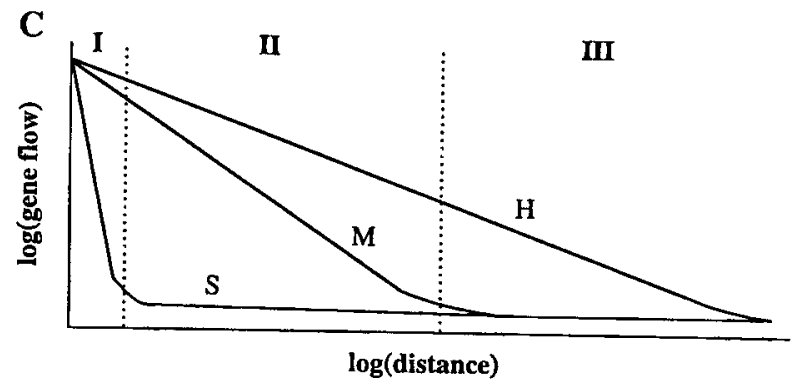

Figure 1: Generalized hypothetical relationships between dispersal ability and isolation by distance (IBD). As shown in the simulation results of Slatkin and Maddison (1990), species of differing dispersal ability ( $S=$ sedentary species, $M=$ moderately mobile species, $H=$ highly mobile species) may have similar IBD slopes but different IBD intercepts $(A)$. In contrast, IBD slopes may vary with dispersal ability, whether IBD intercepts differ with dispersal ability $(B)$ or not $(C)$. In either of these latter situations, we hypothesize that the decline in géne flow should reach an asymptote due to limitations to the degree to which populations can become differentiated. As a result, under either the model represented in $B$ or that shown in $C$, the steepest slopes would be represented by species of different dispersal ability, depending on spatial scale. Specifically, at the smallest scale (zone $I$ ), sedentary species would have the steepest slopes, at intermediate scales (zone $I I$ ), moderately mobile species would have the steepest slopes, and at larger spatial scales (zone $I I I$ ), highly mobile species would have the steepest IBD slopes. 
the most mobile species. It is important to note that the rank order of slopes may vary similarly with spatial scale whether the IBD intercepts of species of differing mobility are different (fig. $1 B$ ) or the same (fig. $1 C$ ). The only way to determine if intercepts vary with dispersal ability is to examine patterns of IBD at the smallest spatial scales. Unfortunately, because few studies to date have examined population-genetic variation in insects at very fine spatial scales $(0-5 \mathrm{~km})$, we are unable herein to elucidate the relationship between IBD intercepts and dispersal ability. Nonetheless, since the average study in our review covered a range of distances separating populations from $41 \mathrm{~km}$ to $1,542 \mathrm{~km}$ (table 1), this review examined the relationship between dispersal ability and IBD slopes over all but the smallest spatial scales.

To test the above hypotheses regarding IBD and dispersal, we obtained averages of the IBD slopes and intercepts of the sedentary, moderately mobile, and highly mobile species/races in each insect family represented in our review. If a species or host race was represented by more than one study, we used the average slope and intercept for that species in calculating the family average. Using family averages as independent data points, we then performed ANOVA to determine the effects of dispersal ability on IBD slopes and intercepts, using a least squares difference (LSD) means separation test (SAS Institute 1990) to resolve differences among the three dispersal categories. Note that the intercepts used in these analyses may not represent the true intercepts for each species, particularly if IBD is steep at spatial scales smaller than the scale of the population-genetic survey for that species. However, these estimated intercepts are useful for comparing IBD relationships over the range of geographic distances at which the species in our review were surveyed.

To test the hypothesis that isolation by distance in phytophagous insects increases as diet breadth decreases, we used the same analytical procedure, comparing IBD slopes and intercepts among monophagous, oligophagous, and polyphagous species. For all analyses of IBD slopes, we used the slopes that were estimated from Mantel's (1967) tests, even in those cases in which slopes were positive, a result not predicted by IBD theory. In all such cases, positive slopes were not statistically significant. To determine if these positive slopes underlie any apparently significant result of either dispersal ability or diet breadth on IBD slope, we repeated analyses revealing a significant effect on IBD slope, but with the nonsignificant positive slopes entered as 0 slope. For the analyses of the relationship between both dispersal ability and diet breadth on patterns of IBD, the fact that we examined IBD across a similar spatial scale for all species meant that we were testing the effects of the ecological attributes of those species on IBD, rather than the effect of spatial scale. Thus, any differences among groups of species that differ either in dispersal ability or diet breadth would reveal the effects of those traits on IBD across the range of distances included in our review.

The reason for not treating species as independent data points in the above ANOVAs is that species do not always represent evolutionarily independent origins of a trait (Ridley 1983). For example, if two species of Helicoverpa moths are both polyphagous because their common ancestor was polyphagous, it would be inappropriate to treat the two species as independent for statistical purposes. Phylogenetic nonindependence is a potential problem faced by all comparative studies such as ours, and there are a variety of ways for dealing with it (discussed in detail in Pagel and Harvey 1988; Harvey and Pagel 1991). In the absence of a phylogeny of the group under consideration (as in the case herein), one of the better ways of limiting phylogenetic nonindependence is the analysis of higher nodes (e.g., Harvey and Zammuto 1985; Krebs et al. 1989). This analysis involves averaging data across species within a higher node (genus, family, etc.), under the reasoning that higher nodes are more evolutionarily independent than lower nodes. Our decision to treat families as evolutionarily independent units is supported by the fact that dispersal varied within six of the eight families for which more than one species/race could be categorized by dispersal. Furthermore, seven of the 10 families represented by more than one species/ race harbored variation in diet breadth (table 1). The variation in dispersal ability and diet breadth within such a high proportion of families indicates that these traits are evolutionarily labile, making it highly unlikely that phylogenetic nonindependence explains the similarity in dispersal and/or diet breadth among species in different families.

The major shortcoming of our use of the higher nodes approach in analyzing the effects of dispersal ability and diet breadth on IBD relationships is that this method subsumes data under family averages, reducing degrees of freedom (Harvey and Pagel 1991). Consequently, for any analyses failing to reveal a significant effect of dispersal or diet breadth on IBD slopes or intercepts, we performed a second analysis in which we treated species/ races as independent data points. A similar result in the two analyses would strongly suggest that the negative result in the first test did not result from reduced degrees of freedom.

To further supplement our analyses of dispersal ability and diet breadth on IBD relationships, we analyzed the effect of these ecological traits on the proportion of studies revealing a statistically significant negative IBD slope. We hypothesized that this proportion would increase as 
both mobility and diet breadth decreased. For these analyses, we could not average across studies, so we treated each study (even multiple studies for a single species) as independent. We used $G$ tests of independence (Sokal and Rohlf 1981) in these proportional tests.

\section{Results}

In our review of isolation by distance in phytophagous insects, we found that 24 of the 53 studies we reviewed $(45 \%)$ revealed a significant decline in gene flow with distance (table 1). The IBD relationships we found ranged from little or no IBD and high gene flow levels among all populations (e.g., Spodoptera exempta), to pronounced IBD (e.g., Pieris [napi] marginalis), to little or no IBD and low levels of gene flow among all populations (e.g., Enchenopa "binotata"-Cercis race). In nearly all IBD relationships, there was tremendous scatter in the data; only four studies had an $r^{2}$ value exceeding 0.5 , and in more than half (13) of the 24 studies with a significant decline in gene flow with distance, $r^{2}$ was less than 0.2 . We found little evidence to suggest that vicariance is an important component of IBD in phytophagous insects; in only five of the 24 studies revealing significant IBD did the relationship appear to be driven by a single geographically isolated population (Ctenopseustis obliquana type I, III, C. obliquana type II, Planotortrix excessana type A [all Tortricidae, from White and Lambert 1995], Coenonympha tullia [Nymphalidae, from Wiernasz 1989], and Andricus quercuscalicis [Cynipidae, from Stone and Sunnucks 1993]). We found no evidence that patterns of IBD differed among the insect orders, as neither IBD slope ( $F=0.304$, df $=5,37, P=.908)$ nor intercept $(F=0.254, \mathrm{df}=5,37, P=.935)$ were influenced by taxonomic order.

The likelihood of detecting a significant decline in gene flow with geographic distance increased with the number of populations in a study $(F=9.266, \mathrm{df}=1,51$, $P=.004$; fig. 2 ). Ten of the 14 studies that included at least 15 populations $(71 \%)$ revealed significant IBD, whereas only 14 of the 39 studies with fewer than 15 populations $(36 \%)$ showed significant $\operatorname{IBD}\left(G_{\mathrm{adj}}=5.198\right.$, $\mathrm{df}=1, P<.05$ ). In contrast, the probability of detecting IBD was not influenced by the number of polymorphic loci surveyed in a study ( $F=2.894$, df $=1,49, P=$ .095).

We found that across a broad range of geographic distances, IBD slopes varied with the dispersal ability of phytophagous insects. In particular, we found that mobility had a significant influence on IBD slope $(F=$ $4.167, \mathrm{df}=2,19, P=.032$; fig. $3 A$ ), with moderately mobile species having significantly steeper IBD slopes than highly mobile species. Sedentary species had inter-

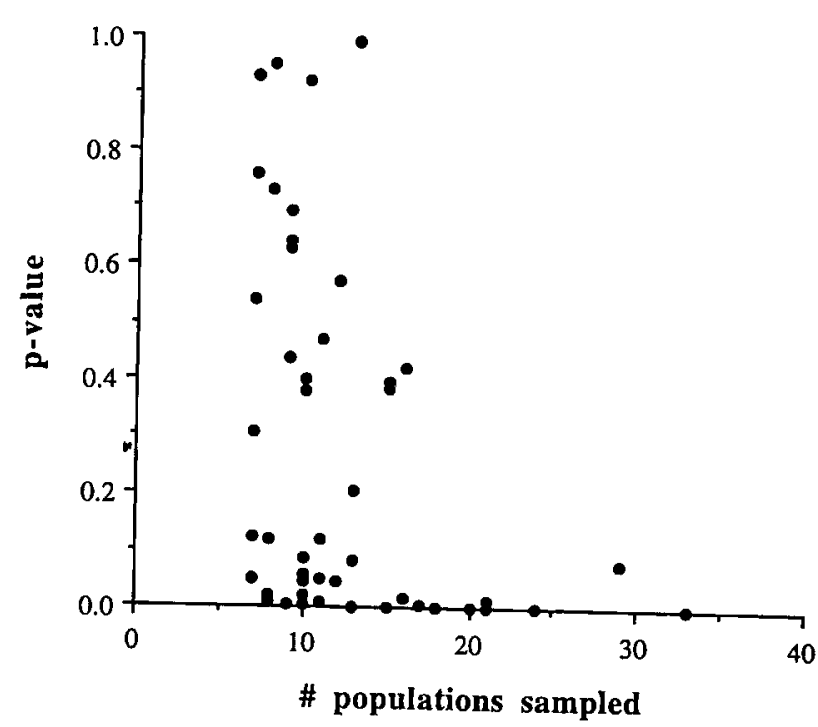

Figure 2: The relationship between the number of populations sampled in a study and the significance of the decline in gene flow with distance ( $P$ value). Angular-transformed $P$ values declined with the number of populations sampled $(F=9.266$, $\mathrm{df}=1,51, P=.004)$, indicating that the likelihood of detecting a significant pattern of isolation by distance improves as the number of populations surveyed increases. Of the 14 studies that included at least 15 populations, $10(71 \%)$ revealed significant isolation by distance $(P<.05)$, whereas only 14 of the 39 studies $(36 \%)$ that included fewer than 15 populations showed a significant decline in gene flow with geographic distance $\left(G_{\mathrm{adi}}=5.198, \mathrm{df}=1, P<0.05\right)$.

mediate slopes that did not differ significantly from the other two dispersal categories. These results were the same whether nonsignificant positive slopes were treated as positive or as 0 . In addition to the effect of dispersal ability on IBD slope, there was a statistical trend suggesting that the proportion of studies revealing a significant decline in gene flow with distance varied with mobility $\left(G_{\text {adj }}=5.392\right.$, df $=2, .10>P>.05$; fig. $\left.4 A\right)$. Furthermore, the proportion of species/races with an IBD slope steeper than -0.5 varied strikingly with dispersal ability; nearly half (five) of the 12 moderately mobile species but none of the sedentary or highly mobile species/races had a slope that steep $\left(G_{\text {adi }}=10.420, \mathrm{df}=\right.$ $2, P<.01$; fig. $4 B$ ). In addition to its influence on IBD slopes, mobility also influenced estimated IBD intercepts $(F=3.999, \mathrm{df}=2,19, P=.036$; fig. $3 B)$, with sedentary species having lower estimated intercepts than moderately mobile species. Highly mobile species had estimated intercepts that were intermediate to, and statistically indistinguishable from, the other two categories of mobility.

There was no evidence to support the hypothesis that diet breadth influences the population-genetic structure 

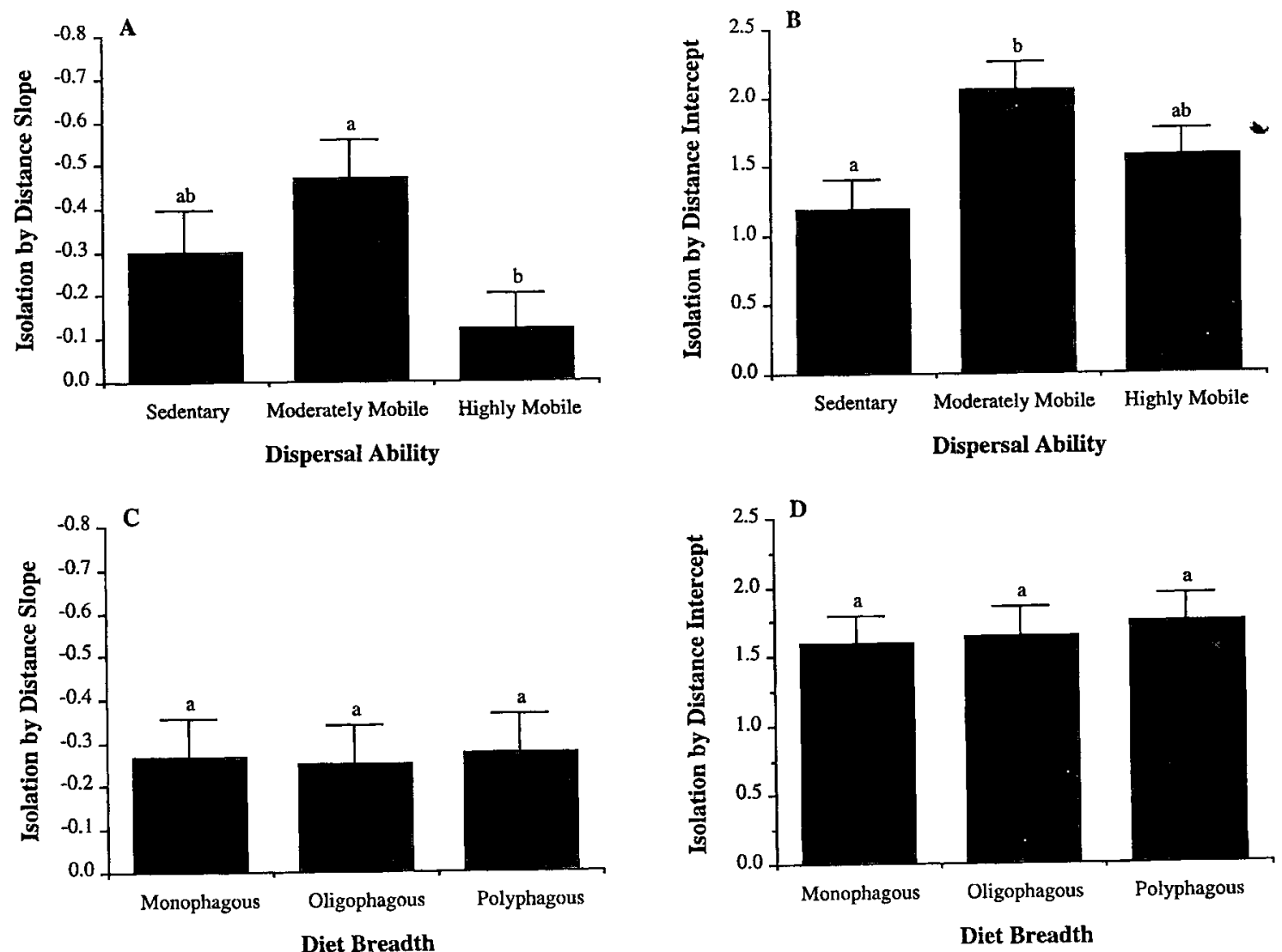

Figure 3: The influence of dispersal ability and diet breadth on patterns of isolation by distance in phytophagous insects. Dispersal ability influences the decline in gene flow with distance; both the slope of the isolation-by-distance relationships $(A)$ and the estimated intercept of those relationships $(B)$ vary among insects that differ in dispersal ability (slope: $F=4.167, \mathrm{df}=2,19, P=$ .032 ; intercept: $F=3.999, \mathrm{df}=2,19, P=.036$ ). In contrast, the diet breadth of phytophagous insects has no influence on either (C) the degree to which gene flow declines with distance $(F=0.014$, df $=2,24, P=.986)$ or $(D)$ the estimated intercept of the isolation-by-distance relationship $(F=0.132 \mathrm{df}=2,24, P=.877)$. Means with different letters differ significantly, as assessed by an LSD means separation test (SAS Institute 1990).

of phytophagous insects. Neither IBD slopes nor intercepts were influenced by the host range of the insects in our review (fig. $3 C, D$ ). This was true for our analyses of family means (slope: $F=0.014$, $\mathrm{df}=2,24, P=.986$; intercept: $F=0.132$, df $=2,24, P=.877$ ), as well as in the analyses in which we treated each species/race as independent (slope: $F=0.020, \mathrm{df}=2,42, P=.980$; intercept: $F=0.420$, df $=2,42, P=.660$ ). These patterns were also supported by the fact that the proportion of studies revealing statistically significant IBD did not vary with host range $\left(G_{\text {ad }}=1.434, \mathrm{df}=2, P>.25\right.$; fig. $4 C$ ).

\section{Discussion}

\section{General Patterns of Isolation by Distance in Phytophagous Insects}

The results of our review indicate that genetic isolation by distance is common in phytophagous insects; a sig- nificant decline in gene flow with distance was evident in nearly half (24) of the 53 studies we examined. This result suggests that allozyme variation among populations is at or nearly at equilibrium in many insect species (Slatkin 1993). Since IBD relationships did not vary across insect orders, it is apparent that over the range of distances in our review, IBD is a widespread phenomenon in insects. Nonetheless, within phytophagous insects, there is considerable variation in the degree to which gene flow declines with distance. We found that, across phytophagous insects, the slope of the relationship between logtransformed gene flow estimates and log-transformed geographic distances ranged from 0.191 to -1.176 , and intercepts ranged from 0.604 to 4.552 . Some species (e.g., the northern corn rootworm Diabrotica barberi, the checkerspot butterfly Euphydryas editha, and the fruit fly Rhagoletis pomonella-esp. the Crataegus race) are characterized by steep declines in gene flow with distance, 

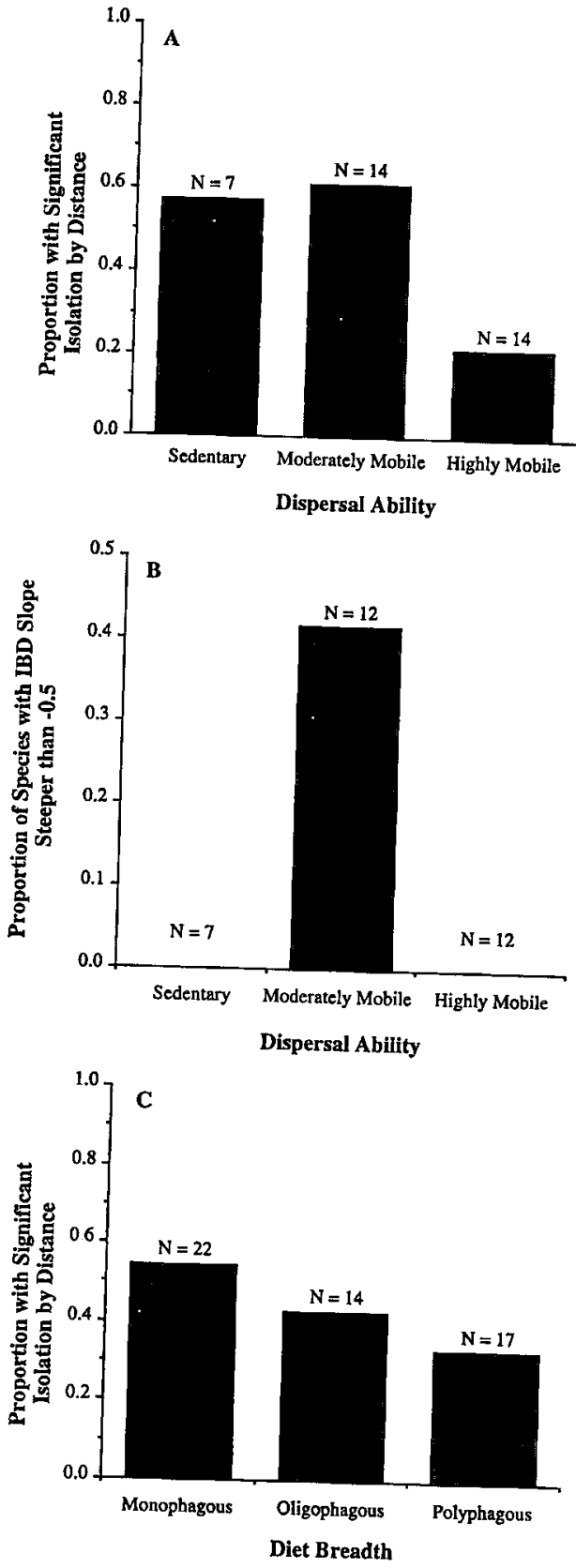

Figure 4: The influence of dispersal ability and diet breadth on isolation by distance in phytophagous insects. $A$, There is a trend suggesting that the proportion of species with significant isolation by distance varies with dispersal ability $\left(G_{\text {adi }}=5.392\right.$, $\mathrm{df}=2, .10>P>.05$ ). $B$, The steepest isolation-by-distance relationships (IBD slope steeper than -0.5 ) are found in species of intermediate dispersal ability $\left(G_{\text {adj }}=10.420\right.$, $\mathrm{df}=2$, $P<.01) . C$, The proportion of species with a significant decline in gene flow with distance is not influenced by insect diet breadth $\left(G_{\text {adj }}=1.434\right.$, df $=2, P>.25$ ). whereas others experience little or no IBD. Of the species in which IBD is weak, some exhibit high levels of gene flow among all populations (e.g., the migratory grasshopper Melanoplus sanguinipes, the saltmarsh planthopper Prokelisia marginata, and the African armyworm Spodoptera exempta), and others feature minimal gene flow at all scales (e.g., the chrysomelid beetle Chrysolina aurichalcea, the swallowtail butterfly Papilio zelicaon, and the agromyzid fly Phytomyza chaerophylli).

In only a few cases did it appear that a significant pattern of IBD was due to reduced gene flow between a geographically outlying population and the remainder of the populations surveyed. Thus, for the majority of studies (19 of 24), the significant decline in gene flow with distance appears to represent true isolation by distance (sensu Wright 1943), as opposed to vicariance. For nearly all insects, IBD relationships were characterized by a lot of scatter; values of $r^{2}$ ranged from 0.00 to 0.64 and were typically less than 0.20 . This was the case even for those species in which the decline in gene flow with distance was statistically significant. The scatter in IBD relationships might be the result of genetic drift and/or extinction/recolonization processes, both of which might alter allele frequencies in populations in a way that weakens any relationship between gene flow and geographic distance (Rosenberg 1989; Preziosi and Fairbairn 1992; Nürnberger and Harrison 1995). However, simulations by Slatkin (1993) revealed that, even when all assumptions of an IBD model are met, IBD relationships can still show considerable scatter. It is also possible that error in the estimation of the allele frequencies in populations contributed to the scatter in IBD relationships (Slatkin and Arter 1991). Nevertheless, although many of the IBD relationships in phytophagous insects exhibit pronounced scatter, the widespread existence of IBD in this group indicates that we must include genetic isolation by distance in our models of the genetic differentiation of phytophagous insect populations.

\section{Influence of Dispersal Ability' and Diet Breadth on Isolation by Distance}

Our review demonstrated that, for phytophagous insects, the relationship between dispersal ability and IBD is consistent with the hypothesis that IBD slopes vary with dispersal ability. We found that over a spatial scale of tens of kilometers to $>1,000 \mathrm{~km}$, moderately mobile species (dispersing 1-20 km) exhibited the steepest IBD relationships, whereas IBD was relatively weak in both sedentary (dispersing $<1 \mathrm{~km}$ ) and highly mobile species (dispersing $>20 \mathrm{~km}$; summarized in fig. 5). We argue that, for highly mobile species, weak or nonexistent IBD is due to broadscale dispersal, which results in extensive gene flow 


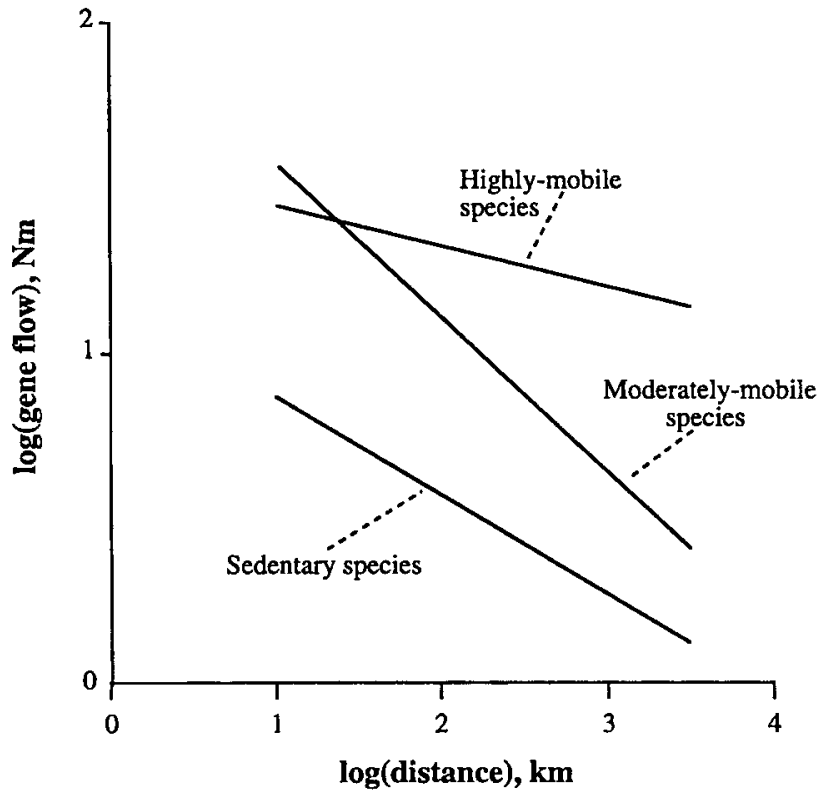

Figure 5: Summary of the influence of dispersal ability on the decline in gene flow with geographic distance in phytophagous insects. The isolation-by-distance relationships for species in the three dispersal categories are based on mean slopes and intercepts for those categories (fig. $3 A, B$ ). Since only a few of the studies in our review included populations separated by less than $10 \mathrm{~km}(\log ($ distance $)=1$ ), we did not plot isolation-bydistance relationships for distances less than $10 \mathrm{~km}$. The relationship between dispersal ability and isolation by distance is consistent with the pattern predicted for the intermediate spatial scale $(I I)$ in figure $1 B$ and $C$ but not with what is predicted in figure $1 A$.

over both small and large distances. Studies of the population-genetic structure of sympatric saltmarsh planthoppers confirm that species of moderate mobility may feature a significant decline in gene flow with distance while highly mobile species show a complete lack of IBD (Peterson and Denno 1997). In sedentary species, weak IBD is apparently due to a very different process. In these poor dispersers, gene flow across the entire spatial scale we examined is weak, allowing populations separated by tens of kilometers to become nearly as differentiated as populations separated by great distances. Preziosi and Fairbairn (1992) have also invoked this argument to explain why populations of a predominately wingless waterstrider, Aquarius remigis, exhibit no pattern of IBD at large spatial scales. It is likely that at very fine spatial scales, sedentary species feature a sharp decline in gene flow with distance, but because exceedingly few studies have examined fine-scale differentiation among populations of sedentary insects, we could not examine this possibility. In contrast to sedentary and highly mobile species, we found that many species of intermediate mobility exhibit steep declines in gene flow with distance over the spatial scale in our review. In these species, gene flow is strong among closely situated populations, apparently due to the ability of these species to disperse among nearby populations. However, gene flow declines with distance, presumably because these species are not capable of dispersing great distances.

It is possible that the apparent relationship between dispersal ability and IBD in phytophagous insects may reflect an underlying relationship between gene flow and some other trait that is confounded with dispersal ability. For example, if population sizes increase with mobility, one would expect $N_{\mathrm{e}} m$ to be higher at a given distance for mobile than for sedentary species, as we found. Similarly, gene flow among populations of highly mobile species might be exaggerated if premating dispersal occurs more frequently in such species. However, it is difficult to see how such differences in population size and or premating dispersal would lead to the differing IBD slopes that we found among species in the different dispersal categories.

It is also possible that highly mobile and sedentary species are characterized by a greater frequency of nonequilibrium conditions than moderately mobile species, explaining the shallower IBD slopes in the most- and least-mobile species. If this were the case, it would be likely that the differences in the frequency of nonequilibrium conditions were the direct result of differences in mobility. For example, it is possible that recent range expansions have resulted in a lack of IBD and apparently extensive gene flow in highly mobile species. Furthermore, nonequilibrium conditions resulting from a complete cessation of ongoing gene flow may explain the lack of IBD and minimal gene flow among populations of sedentary species (Slatkin 1993). If this were the case, our assertion that dispersal ability influences population-genetic structure would remain true.

To our knowledge, this is the first study to examine the influence of dispersal ability on IBD in any group of organisms. The striking relationship between dispersal and IBD in insects suggests that our understanding of gene flow among natural populations would benefit by incorporating the effect of dispersal ability on IBD slopes into population-genetic models. This would be particularly true if the results for insects reflect a general pattern. To determine if this is the case, we should examine whether similar relationships occur in other taxa (e.g., plants, birds) that harbor substantial variation in dispersal ability. In addition, we should conduct population-genetic studies to allow us to better understand the influence of dispersal ability on patterns of IBD at the finest spatial scales, since current data for these spatial scales are woefully scanty. 
In contrast to the effect of dispersal on IBD, we found no evidence to suggest that the decline in gene flow with distance in phytophagous insects is influenced by diet breadth. Isolation-by-distance slopes and intercepts were the same whether insects utilized plants only in a single genus, plants in multiple genera within a family, or plants in multiple families. Furthermore, the likelihood of detecting a significant decline in gene flow with distance did not vary with diet breadth. It is highly unlikely that these results were due to a lack of statistical power, since the analysis using all species as independent data points also indicated no trend of an effect of diet breadth on IBD. Thus, there is no evidence that the degree of dietary specialization influences gene flow among populations of phytophagous insects.

This result was surprising since numerous authors have hypothesized that suitable habitat for specialists should be patchier than that which can be utilized by generalists, and therefore, gene flow should be restricted among populations of specialists compared to generalists (reviewed in Futuyma and Moreno 1988). Indeed, this hypothesized restriction in gene flow is a key element of the specialization-speciation hypothesis, which states that specialist lineages should be more prone to speciate than generalist lineages (Fryer 1959; Mayr 1963; Stanley 1979; Price 1980; Vrba 1984; Futuyma and Moreno 1988). Efforts to demonstrate that specialists do show higher rates of speciation have met with mixed support, in part because specialists are also thought by many to be more vulnerable to extinction (Huxley 1942; Rensch 1960; Futuyma and Moreno 1988; Mitter et al. 1988; Moran 1988; Wiegmann et al. 1993). Consequently, a better approach for examining the specialization-speciation hypothesis may be to examine its underlying components. Although the link between ecological specialization and gene flow has not been rigorously examined in any other group of organisms, the results reported herein, as well as the results of our earlier review of species-specific gene flow estimates (Peterson and Denno 1998) cast doubt on the assumption that populations of specialists are more genetically subdivided than populations of generalists.

The possibility remains that we would have discovered an effect of diet breadth on IBD had we compared strict monophages (insects utilizing a single host plant species) with insects characterized by greater diet breadth. Unfortunately, there were too few strictly monophagous species in our review to permit this analysis. Nonetheless, we would be surprised to find that strict monophages exhibited a different pattern of IBD than insects with broader host ranges, given that IBD did not differ at all between highly polyphagous species and species utilizing plants in a single genus. Rather, we feel that our results accurately reveal the lack of an effect of diet breadth on IBD in phytophagous insects. We suggest that the explanation for this result is that, if suitable habitats are indeed patchier for specialists than for generalists, the scale of that increased patchiness is trivial for most dispersing insects. Thus, either the habitats used by specialist herbivores are not patchier than those used by generalists or any increases in habitat patchiness associated with dietary specialization occur over such a fine spatial scale as to have no influence on gene flow. Alternatively, it is possible, though not likely, that specialists are characterized by greater dispersal ability $(m)$ or by greater effective population sizes $\left(N_{\mathrm{e}}\right)$ than generalists. Either of these differences could negate any reduction in gene flow $\left(N_{\mathrm{e}} m\right)$ due to increased habitat patchiness experienced by specialists.

\section{The Design of Studies of Genetic Isolation by Distance}

In addition to demonstrating the effects of life history on IBD in phytophagous insects, our review provides insights for the design of studies of IBD using allozyme markers. First, allozymes are clearly useful for studying IBD, as nearly half of the studies we reviewed showed a pattern of IBD using these markers. A somewhat surprising result was that the number of loci used had no effect on the probability of discovering a significant isolating effect of distance. This result was surprising since even selectively neutral loci would not be expected to exhibit identical population structure. Rather, they should exhibit random variation around some mean value, due to the stochastic effects of genetic drift. In addition, since it is known that some allozyme loci are under selection (Watt et al. 1983, 1985; Anderson and Oakeshott 1984; Begun and Aquadro 1994), there is even greater reason to expect that different loci should not behave identically. The fact that patterns of isolation by distance for the insects included in our review are not sensitive to the number of loci surveyed suggests that individual loci tend to provide the same estimate of population structure. This is particularly interesting since it has been argued that because mtDNA is a single, linked locus, estimates of gene flow using mtDNA might be biased compared to estimates using multilocus markers, such as allozymes (Mitton 1994; Roderick 1996). Our data suggest that the bias associated with using a small number of loci might be inconsequential and that the number of loci should not be the principal consideration in designing studies of IBD. However, it apparently is important to include a minimum number of populations in an IBD study, to maximize the probability of detecting a significant decline in gene flow with distance. Based on our results, we recommend that allozyme-based studies of IBD include 
at least 15 populations. With fewer than 15 populations, one might erroneously conclude that IBD is lacking in a species in which gene flow does decline with distance. It is important to note that the relationship between dispersal ability and IBD demonstrated in this article was not confounded by variation in sampling intensity, as the proportion of studies using at least 15 populations did not vary significantly across the three dispersal categories $\left(G_{\text {adj }}=3.42, \mathrm{df}=2, P>.10\right)$.

Spatial scale is also an important element to consider in the design of IBD studies, to ensure that populations are sampled over a sufficient spatial scale to allow detection of IBD. For example, populations of the lycaenid butterfly Euphilotes enoptes, adults of which rarely disperse more than $1 \mathrm{~km}$ (Peterson 1997), do not show evidence for IBD over distances up to $30 \mathrm{~km}$ (Peterson 1995). However, when examined over distances up to $405 \mathrm{~km}$, a clear pattern of IBD emerges in this species (Peterson 1996). It is critical not to underestimate the scale over which isolation by distance occurs, since the geographic scale of gene flow in general exceeds the scale of dispersal (Slatkin 1985; Peterson 1996; Roderick 1996).

Studies of genetic isolation by distance offer exciting new insights for evolutionary biology. These studies provide a more detailed picture of gene flow and population-genetic differentiation than studies that generate single, overly simplistic estimates of gene flow among groups of populations. In particular, studies of IBD explicitly assess the spatial scale of gene flow, allowing us to better understand the scale of genetic differentiation among natural populations. Thus, through comparative studies such as this one, it is possible to determine how ecological factors influence the extent of gene flow among populations. Ultimately, these studies might help us better understand how such ecological factors influence both the scale over which adaptations can evolve in response to locally varying selective regimes and the probability of speciation.

\section{Acknowledgments}

We thank S. Mopper and S. Strauss for providing the excuse to pull together the literature on the population-genetic structure of phytophagous insects. We also thank R. Chapman, F. Chew, and C. Mitter for contributing and/ or verifying ecological data. The ideas developed in this article were improved through discussions with $\mathrm{A}$. de Queiroz, B. Farrell, S. Kelley, A. McCune, and C. Mitter. This manuscript benefited from the careful review of $\mathrm{T}$. Markow, M. Slatkin, C. Yoon, and two anonymous reviewers. M. Slatkin generously provided a copy of a computer program for estimating isolation by distance. This program was modified for use on a personal computer by M. Milgroom. In addition, E. Russek-Cohen offered statistical assistance, for which we are grateful. This research was supported by National Science Foundation Grant DEB-9527846 to R.F.D., and Maryland Agricultural Experiment Station Competitive Grant ENTO-9510 to M.A.P. and R.F.D.

\section{Literature Cited}

Anderson, P. R., and J. G. Oakeshott. 1984. Parallel geographical patterns of allozyme variation in two sibling Drosophila species. Nature (London) 308:729-731.

Avise, J. C., J. Arnold, R. M. Ball, E. Bermingham, T. Lamb, J. E. Neiger, C. A. Reeb, and N. C. Saunders. 1987. Intraspecific phylogeography: the mitochondrial DNA bridge between population genetics and systematics. Annual Review of Ecology and Systematics 18: 489-522.

Baruffi, L., G. Damiani, C. R. Guglielmino, C. Bandis, A. R. Malacrida, and G. Gasperi. 1995. Polymorphism within and between populations of Ceratitis capitata: comparison between RAPD and multilocus enzyme electrophoresis data. Heredity 74:425-437.

Begun, D. J., and C. F. Aquadro. 1994. Evolutionary inferences from DNA variation at the 6-phosphogluconate dehydrogenase locus in natural populations of Drosophila: selection and geographic differentiation. Genetics 136:155-171.

Beregovoy, V. H., and D. S. Gill. 1986. Isozyme polymorphism in the sunflower moth. Journal of Heredity 77: 101-105.

Berlocher, S. H. 1984. Genetic changes coinciding with the colonization of California by the walnut husk fly, Rhagoletis completa. Evolution 38:906-918.

. 1995. Population structure of Rhagoletis mendax, the blueberry maggot. Heredity 74:542-555.

Britten, H. B., and P. F. Brussard. 1992. Genetic divergence and the Pleistocene history of the alpine butterflies Boloria improba (Nymphalidae) and the endangered Boloria acrocnema (Nymphalidae) in western North America. Canadian Journal of Zoology 70:539548.

Britten, H. B., and R. W. Rust. 1996. Population structure of a sand dune-obligate beetle, Eusattus muricatus, and its implications for dune management. Conservation Biology 10:647-652.

Britten, H. B., P. F. Brussard, D. D. Murphy, and G. T. Austin. 1994. Colony isolation and isozyme variability of the western seep fritillary, Speyeria nokomis apacheana (Nymphalidae) in the western Great Basin. Great Basin Naturalist 54:97-105. 
Britten, H. B., P. F. Brussard, D. D. Murphy, and P. R. Ehrlich. 1995. A test for isolation-by-distance in central Rocky Mountain and Great Basin populations of Edith's checkerspot butterfly (Euphydryas editha). Journal of Heredity 86:204-210.

Brown, I. L., and P. R. Ehrlich. 1980. Population biology of the checkerspot butterfly, Euphydryas chalcedona: structure of the Jasper Ridge colony in California. Oecologia (Berlin) 47:239-251.

Bush, G. L. 1975. Modes of animal speciation. Annual Review of Ecology and Systematics 6:339-364.

Caccone, A., and V. Sbordoni. 1987. Molecular evolutionary divergence among North American cave crickets. I. Allozyme variation. Evolution 41:1198-1214.

Chapco, W., and M. J. Bidochka. 1986. Genetic variation in prairie populations of Melanoplus sanguinipes, the migratory grasshopper. Heredity 56:397-408.

Chew, F. 1981. Coexistence and local extinction in two pierid butterflies. American Naturalist 118:655-672.

Costa, J. T., III, and K. G. Ross. 1994. Hierarchical genetic structure and gene flow in macrogeographic populations of the eastern tent caterpillar (Malacosoma americanum). Evolution 48:1158-1167.

Covell, C. V., Jr. 1984. A field guide to the moths of eastern North America. Houghton Mifflin, Boston.

Daly, J. C., and P. Gregg. 1985. Genetic variation in $\mathrm{He}$ liothis in Australia: species identification and gene flow in the two pest species $H$. armigera (Hübner) and $H$. punctigera Wallengren (Lepidoptera: Noctuidae). Bulletin of Entomological Research 75:169-184.

den Boer, M. H. 1978. Isoenzymes and migration in the African armyworm Spodoptera exempta (Lepidoptera: Noctuidae). Journal of Zoology (London) 185:539_ 553.

Doherty, P. J., S. Planes, and P. Mather. 1995. Gene flow and larval duration in seven species of fish from the Great Barrier Reef. Ecology 76:2373-2391.

Duijm, M., and L. Oudman. 1983. Interspecific mating in Ephippiger (Orthoptera: Tettigonioidea). Tijdschrift voor Entomologie 126:97-108.

Eanes, W. F., and R. K. Koehn. 1978. An analysis of genetic structure in the monarch butterfly, Danaus plexippus L. Evolution 32:784-797.

Ehrlich, P. R., and P. H. Raven. 1964. Butterflies and plants: a study in coevolution. Evolution 18:586-608.

Endler, J. A. 1977. Geographic variation, speciation, and clines. Princeton University Press, Princeton, N.J.

. 1979. Gene flow and life history patterns. Genetics 93:263-284.

Farrell, B. D., and C. Mitter. 1994. Adaptive radiation in insects and plants: time and opportunity. American Zoologist 34:57-69.

Feder, J. L., and G. L. Bush. 1989. Gene frequency clines for host races of Rhagoletis pomonella in the midwestern United States. Heredity 63:245-266.

Feder, J. L., C. A. Chilcote, and G. L. Bush. 1990. The geographic pattern of genetic differentiation between host associated populations of Rhagoletis pomonella (Diptera: Tephritidae) in the eastern United States and Canada. Evolution 44:570-594.

Frey, J. E., T. Latscha, and D. B. McKey. 1990. Genetic differentiation and speciation in leaf-mining flies of the genus Phytomyza. Entomologia Experimentalis et Applicata 57:191-200.

Fryer, G. 1959. Some aspects of evolution in Lake Nyasa. Evolution 13:440-451.

Futuyma, D. J., and G. C. Mayer. 1980. Non-allopatric speciation in animals. Systematic Zoology 29:254-271.

Futuyma, D. J., and G. Moreno. 1988. The evolution of ecological specialization. Annual Review of Ecology and Systematics 19:207-233.

Geiger, H., and A. M. Shapiro. 1992. Genetics, systematics and evolution of holarctic Pieris napi species group populations (Lepidoptera, Pieridae). Zeitschrift für Zoologische Systematik und Evolutionsforschung 30:100122.

Gill, P. 1981. Allozyme variation in sympatric populations of British grasshoppers-evidence of natural selection. Biological Journal of the Linnean Society 16: 83-91.

Govindaraju, D. R. 1988. Relationship between dispersal ability and gene flow in plants. Oikos 52:31-35.

Guttman, S. I., and L. A. Weigt. 1989. Macrogeographic genetic variation in the Enchenopa binotata complex (Homoptera: Membracidae). Annals of the Entomological Society of America 82:156-165.

Haag, K. L., A. M. Araújo, and A. Zaha. 1993. Genetic structure of natural populations of Dryas iulia (Lepidoptera: Nymphalidae) revealed by enzyme polymorphism and mitochondrial DNA (mtDNA) restriction fragment length polymorphism (RFLP). Biochemical Genetics 31:449-460.

Haddock, R. C. 1984. Orientation and movement of the northern corn rootworm, Diabrotica barberi (Coleoptera: Chrysomelidae), over large and small distances. Ph.D. diss. Cornell University, Ithaca, N.Y.

Hagen, R. H. 1990. Population structure and host use in hybridizing subspecies of Papilio glaucus (Lepidoptera: Papilionidae). Evolution 44:1914-1930.

Hanks, L. M., and R. F. Denno. 1994. Local adaptation in the armored scale insect Pseudalacaspis pentagona (Homoptera: Diaspididae). Ecology 75:2301-2310.

Harrison, S. 1989. Long-distance dispersal and colonization in the Bay checkerspot butterfly, Euphydryas editha bayensis. Ecology 70:1236-1243.

Harvey, G. T. 1996. Population genetics of the spruce 
budworm, Choristoneura fumiferana (Clem.) Freeman (Lepidoptera: Tortricidae), in relation to geographical and population density differences. Canadian Entomologist 28:219-243.

Harvey, P. H., and M. D. Pagel. 1991. The comparative method in evolutionary biology. Oxford University Press, Oxford.

Harvey, P. H., and R. M. Zammuto. 1985. Patterns of mortality and age at first reproduction in natural populations of mammals. Nature (London) 315:319-320.

Hastings, A., and S. Harrison. 1994. Metapopulation dynamics and genetics. Annual Review of Ecology and Systematics 25:167-188.

Hellberg, M. E. 1994. Relationships between inferred levels of gene flow and geographic distance in a philopatric coral, Balanophyllia elegans. Evolution 48:18291854.

Higby, P. K., and M. W. Stock. 1982. Genetic relationships between two sibling species of bark beetles (Coleoptera: Scolytidae), Jeffrey pine beetle and mountain pine beetle, in northern California. Annals of the Entomological Society of America 75:668-674.

Holdren, C. E., and P. R. Ehrlich. 1982. Ecological determinants of food plant choice in the checkerspot butterfly Euphydryas editha in Colorado. Oecologia (Berlin) 52:417-423.

Huxley, J. S. 1942. Evolution: the modern synthesis. Allen \& Unwin, London.

Johnson, C. G. 1969. Migration and dispersal of insects by flight. Methuen, London.

Kimura, M., and G. H. Weiss. 1964. The stepping stone model of population structure and the decrease of genetic correlation with distance. Genetics 49:561-576.

King, P. S. 1987. Macro- and microgeographic structure of a spatially subdivided beetle species in nature. Evolution 41:401-416.

Krebs, J. R., D. F. Sherry, S. D. Healy, V. H. Perry, and A. L. Vaccarino. 1989. Hippocampal specialization in food-storing birds. Proceedings of the National Academy of Sciences of the USA 86:1399-1392.

Latorre, A., C. Hernández, D. Martínez, J. A. Castro, M. Ramón, and A. Moya. 1992. Population structure and mitochondrial DNA gene flow in Old World populations of Drosophila subobscura. Heredity 68:15-24.

Liebherr, J. K. 1988. Gene flow in ground beetles (Coleoptera: Carabidae) of differing habitat preferences and flight-wing development. Evolution 42:129-137.

Loxdale, H. D., and C. P. Brookes. 1988. Electrophoretic study of enzymes from cereal aphid populations. V. Spatial and temporal genetic similarity of holocyclic populations of the bird-cherry oat aphid, Rhopalosiphum padi (L.) (Hemiptera: Aphididae), in Britain. Bulletin of Entomological Research 78:241-249.
Manly, B. F. J. 1991. Randomization and Monte Carlo methods in biology. Chapman \& Hall, London.

. 1992. RT, version 1.02, a program for randomization testing. Western EcoSystems Technology, Cheyenne, Wyo.

Mantel, N. 1967. The detection of disease clusteing and a generalized regression approach. Cancer Research 27: 209-220.

Maruyama, T. 1971. Analysis of population structure. II. Two-dimensional stepping-stone models of finite length and other geographically structured populations. Annals of Human Genetics 35:179-196.

Maxwell, C. W., and E. C. Parsons. 1968. The recapture of marked apple maggot adults in several orchards from one release point. Journal of Economic Entomology 61:1157-1159.

May, B., D. E. Leonard, and R. D. Vadas. 1977. Electrophoretic variation and sex linkage in spruce budworm. Journal of Heredity 68:355-359.

May, R. M., J. A. Endler, and R. E. McMurtrie. 1975. Gene frequency clines in the presence of selection opposed by gene flow. American Naturalist 109:659-676.

Mayr, E. 1963. Animal species and evolution. Harvard University Press, Cambridge, Mass.

McCauley, D. E. 1991. The effect of host plant patch size variation on the population structure of a specialist herbivore insect, Tetraopes tetraophthalmus. Evolution 45:1675-1684.

McCauley, D. E., M. J. Wade, F. J. Breden, and M. Wohltman. 1988. Spatial and temporal variation in group relatedness: evidence from the imported willow leaf beetle. Evolution 42:184-192.

McDonald, I. C., J. L. Krysan, and O. A. Johnson. 1985. Genetic variation within and among geographic populations of Diabrotica barberi (Coleoptera: Chrysomelidae). Annals of the Entomological Society of America 78:271-278.

McKechnie, S. W., P. R. Ehrlich, and R. R. White. 1975. Population genetics of Euphydryas butterflies. I. Genetic variation and the neutrality hypothesis. Genetics 81:571-594.

McMullen, L. H., and S. F. Condrashoff. 1973. Notes on dispersal, longevity and overwintering of adult Pissodes strobi (Peck) (Coleoptera: Curculionidae) on Vancouver Island. Journal of the Entomological Society of British Columbia 70:22-26.

McPheron, B. A. 1990. Genetic structure of apple maggot fly (Diptera: Tephritidae) populations. Annals of the Entomological Society of America 83:568-577.

Mitter, C., B. Farrell, and B. Wiegmann. 1988. The phylogenetic study of adaptive zones: has phytophagy promoted insect diversification? American Naturalist 132: $107-128$. 
Mitton, J. B. 1994. Molecular approaches to population biology. Annual Review of Ecology and Systematics 25: 45-69.

Mopper, S. 1996. Adaptive genetic structure in phytophagous insect populations. Trends in Ecology \& Evolution 11:235-238.

Moran, N. A. 1988. The evolution of host-plant alternation in aphids: evidence for specialization as a dead end. American Naturalist 132:681-706.

Mulkern, G. B., K. P. Pruess, H. Knutson, A. F. Hagen, J. B. Campbell, and J. D. Lambley. 1969. Food habits and preferences of grassland grasshoppers of the north central Great Plains. North Dakota Agricultural Experiment Station Bulletin 481:1-32.

Murphy, D. D., and P. R. Ehrlich. 1983. Biosystematics of the Euphydryas of the central Great Basin with the description of a new subspecies. Journal of Research on the Lepidoptera 22:254-261.

Nagylaki, T. 1976. The decay of genetic variability in geographically structured populations. Theoretical Population Biology 10:70-82.

Namkoong, G., J. A. Richmond, J. H. Roberds, L. B. Nunnally, B. C. McClain, and J. L. Tyson. 1982. Population genetic structure of Nantucket pine tip moth. Theoretical and Applied Genetics 63:1-7.

Napolitano, M., and H. Descimon. 1994. Genetic structure of French populations of the mountain butterfly Parnassius mnemosyne L. (Lepidoptera: Papilionidae). Biological Journal of the Linnean Society 53:325341.

Napolitano, M., H. Geiger, and H. Descimon. 1988. Structure démographique et génétique de quatre populations provençales de Parnassius mnemosyne (L.) (Lepidoptera: Papilionidae): isolement et polymorphisme dans des populations "menacées." Génétique, Séléction, Evolution 20:51-62.

Nei, M. 1973. Analysis of gene diversity in subdivided populations. Proceedings of the National Academy of Sciences of the USA 70:3321-3323.

Nürnberger, B., and R. G. Harrison. 1995. Spatial population structure in the whirligig beetle Dineutus assimilis: evolutionary inferences based on mitochondrial DNA and field data. Evolution 49:266-275.

Oudman, L., M. Duijm, and W. Landman. 1990. Morphological and allozymic variation in the Ephippiger ephippiger complex (Orthoptera, Tettigonioidea). Netherlands Journal of Zoology 40:454-483.

Pagel, M. D., and P. H. Harvey. 1988. Recent developments in the analysis of comparative data. Quarterly Review of Biology 63:413-440.

Palumbi, S. R. 1992. Marine speciation on a small planet. Trends in Ecology \& Evolution 7:114-118.
Palumbi, S. R., and C. S. Baker. 1994. Contrasting population structure from nuclear intron sequences and mtDNA of humpback whales. Molecular Biology and Evolution 11:426-435.

Pashley, D. P., S. J. Johnson, and A. N. Sparks. 1985. Genetic population structure of migratory moths: the fall armyworm (Lepidoptera: Noctuidae). Annals of the Entomological Society of America 78:756-762.

Peterson, M. A. 1995. Phenological isolation, gene flow and developmental differences among low- and highelevation populations of Euphilotes enoptes (Lepidoptera: Lycaenidae). Evolution 49:446-455.

1996. Long-distance gene flow in the sedentary buttërfly, Euphilotes enoptes (Lepidoptera: Lycaenidae). Evolution 50:1990-1999.

- 1997. Host plant phenology and butterfly dispersal: causes and consequences of uphill movement. Ecology 78:167-180.

Peterson, M. A., and R. F. Denno. 1997. The influence of intraspecific variation in dispersal strategies on the genetic structure of planthopper populations. Evolution $51: 1189-1206$.

1998. Life history strategies and the genetic structure of phytophagous insect populations. Pages 263-322 in S. Mopper and S. Strauss, eds. Genetic structure and local adaptation in natural insect populations: effects of ecology, life history, and behavior. Chapman \& Hall, New York.

Phillips, T. W., and G. N. Lanier. 1985. Genetic divergence among populations of the white pine weevil, Pissodes strobi (Coleoptera: Curculionidae). Annals of the Entomological Society of America 78:744-750.

Porter, A. H. 1990. Testing nominal species boundaries using gene flow statistics: the taxonomy of two hybridizing admiral butterflies (Limenitis: Nymphalidae). Systematic Zoology 39:131-147.

Porter, A. H., and H. Geiger. 1988. Genetic and phenotypic population structure of the Coenonympha tullia complex (Lepidoptera: Nymphalidae: Satyrinae) in California: no evidence for species boundaries. Canadian Journal of Zoology 66:2751-2765.

Preziosi, R. F., and D. J. Fairbairn. 1992. Genetic population structure and levels of gene flow in the stream dwelling waterstrider, Aquarius (= Gerris) remigis (Hemiptera: Gerridae). Evolution 46:430-444.

Price, P. W. 1980. The evolutionary biology of parasites. Princeton University Press, Princeton, N.J.

Radtkey, R. R., and M. C. Singer. 1995. Repeated reversals of host-preference evolution in a specialist insect herbivore. Evolution 49:351-359.

Rainey, R. C. 1979. Dispersal and redistribution of some Orthoptera and Lepidoptera by flight. Mitteilungen 
der Schweizerischen Entomologischen Gesellschaft 52: 125-132.

Rank, N. E. 1992. A hierarchical analysis of genetic differentiation in a montane leaf beetle Chrysomela aeneicollis (Coleoptera: Chrysomelidae). Evolution 46:10971111.

Rensch, B. 1960. Evolution above the species level. Columbia University Press, New York.

Rice, W. R., and E. E. Hostert. 1993. Laboratory experiments on speciation: what have we learned in 40 years? Evolution 47:1637-1653.

Richards, O. W., and N. Waloff. 1954. Studies on the biology and population dynamics of British grasshoppers. Anti-Locust Bulletin 17:1-182.

Ridley, M. 1983. The explanation of organic diversity: the comparative method and adaptations for mating. Oxford University Press, Oxford.

Roderick, G. K. 1996. Geographic structure of insect populations: Gene flow, phylogeography, and their uses. Annual Review of Entomology 41:325-352.

Rosenberg, R. H. 1989. Genetic differentiation among populations of Weidemeyer's admiral butterfly. Canadian Journal of Zoology 67:2294-2300.

Runyeon, H., and H. C. Prentice. 1996. Genetic structure in the species-pair Silene vulgaris and $S$. uniflora (Caryophyllaceae) on the Baltic island of Oeland. Ecography 19:181-193.

Sakanoue, S., and S. Fujiyama. 1987. Allozymic variation among geographic populations of Chrysolina aurichalcea (Coleoptera, Chrysomelidae). Kontyû 55:437-449.

SAS Institute. 1990. SAS user's guide, version 5. SAS Institute, Cary, N.C.

Schuster, W. S., D. L. Alles, and J. B. Mitton. 1989. Gene flow in limber pine: evidence from pollination phenology and genetic differentiation along an elevational gradient. American Journal of Botany 76:1395-1403.

Scott, J. A. 1986. The butterflies of North America. Stanford University Press, Stanford, Calif.

Shapiro, A. M. 1974. Butterflies and skippers of New York State. Search Agriculture 4:1-60.

_. 1982. A new elevational record for Pieris protodice in California (Lepidoptera: Pieridae). Pan-Pacific Entomologist 58:162.

Shapiro, A. M., and H. Geiger. 1986. Electrophoretic confirmation of the species status of Pontia protodice and $P$. occidentalis (Pieridae). Journal of Research on the Lepidoptera. 25:39-47.

Shields, O. 1967. Hilltopping: an ecological study of summit congregation behavior of butterflies on a southern California hill. Journal of Research on the Lepidoptera 6:69-178.

Shulman, M. J., and E. Bermingham. 1995. Early life his- tories, ocean currents, and the population genetics of Caribbean reef fishes. Evolution 49:897-910.

Slatkin, M. 1973. Gene flow and selection in a cline. Genetics 75:733-756.

- 1985. Gene flow in natural populations. Annual Review of Ecology and Systematics 16:393-430.

- 1987. Gene flow and the geographic structure of natural populations. Science (Washington, 9.C.) 236: 787-792.

- 1993. Isolation by distance in equilibrium and non-equilibrium populations. Evolution 47:264-279. methods in population genetics. American Naturalist 138:499-517.

Slatkin, M., and W. P. Maddison. 1990. Detecting isolation by distance using phylogenies of genes. Genetics 126:249-260.

Sluss, T. P., and H. M. Graham. 1979. Allozyme variation in natural populations of Heliothis virescens. Annals of the Entomological Society of America 72:317-322.

Sokal, R. R., and F. J. Rohlf. 1981. Biometry. 2d ed. W. H. Freeman, New York.

Sokal, R. R., N. L. Oden, and J. S. F. Barker. 1987. Spatial structure in Drosophila buzzatii populations: simple and directional spatial autocorrelation. American Naturalist 129:122-142.

Sparks, A. N., R. D. Jackson, J. E. Carpenter, and R. A. Muller. 1986. Insects captured in light traps in the Gulf of Mexico. Annals of the Entomological Society of America 79:132-139.

Stanley, S. M. 1979. Macroevolution: pattern and process. W. H. Freeman, San Francisco.

Stock, M. W., G. D. Amman, and P. K. Higby. 1984. Genetic variation among mountain pine beetle (Dendroctonus ponderosae) (Coleoptera: Scolytidae) populations from seven western states. Annals of the Entomological Society of America 77:760-764.

Stone, G. W., and P. Sunnucks. 1993. Genetic consequences of an invasion through a patchy environment-the cynipid gallwasp Andricus quercuscalicis (Hymenoptera: Cynipidae). Molecular Ecology 2:251268.

Suzuki, K. 1978. Discovery of a flying population in Chrysolina aurichalcea (Mannerheim) (Coleoptera: Chrysomelidae). Kontyû 46:549-551.

Teetes, G. L., and N. M. Randolph. 1969. Some new host plants of the sunflower moth in Texas. Journal of Economic Entomology 62:264-265.

Tong, M. L., and A. M. Shapiro. 1989. Genetic differentiation among California populations of the anise swallowtail butterfly, Papilio zelicaon Lucas. Journal of the Lepidopterists' Society 43:217-228. 
Vrba, E. S. 1984. Evolutionary pattern and process in the sister-group Alcelaphini-Aepycerotini (Mammalia: Bovidae). Pages 62-79 in N. Eldredge and S. M. Stanley, eds. Living fossils. Springer, New York.

Wade, M. J., and D. E. McCauley. 1988. Extinction and recolonization: their effects on the genetic differentiation of local populations. Evolution 42:995-1005.

Waples, R. S. 1987. A multispecies approach to the analysis of gene flow in marine shore fishes. Evolution 41:385-400.

Waring, G. L., W. G. Abrahamson, and D. J. Howard. 1990. Genetic differentiation among host-associated populations of the gallmaker Eurosta solidaginis (Diptera: Tephritidae). Evolution 44:1648-1655.

Watt, W. B., R. C. Cassin, and M. S. Swan. 1983. Adaptation at specific loci. III. Field behavior and survivorship differences among Colias PGI genotypes are predictable from in vitro biochemistry. Genetics 103:725739.

Watt, W. B., P. A. Carter, and S. M. Blower. 1985. Adaptation at specific loci. IV. Differential mating success among glycolytic allozyme genotypes of Colias butterflies. Genetics 109:157-175.

Weir, B. S., and C. C. Cockerham. 1984. Estimating Fstatistics for the analysis of population structure. Evolution 38:1358-1370.

White, C. S., and D. M. Lambert. 1994. Genetic differences among pheromonally distinct New Zealand leafroller moths. Biochemical Systematics and Ecology 22: 329-339.

-1995. Genetic continuity within, and discontinuities among, populations of leafroller moths with distinct sex-pheromones. Heredity 75:243-255.

Whitlock, M. C., and D. E. McCauley. 1990. Some population genetic consequences of colony formation and extinction: genetic correlations within founding groups. Evolution 44:1717-1724.

Wiegmann, B. M., C. Mitter, and B. Farrell. 1993. Diver- sification of carnivorous parasitic insects: extraordinary radiation or specialized dead end? American Naturalist 142:737-754.

Wiernasz, D. C. 1989. Ecological and genetic correlates of range expansion in Coenonympha tullia. Biological Journal of the Linnean Society 38:197-214.

Willhite, E. A., and M. W. Stock. 1983. Genetic variation among western spruce budworm (Choristoneura occidentalis) (Lepidoptera: Tortricidae) outbreaks in Idaho and Montana. Canadian Entomologist 115:41-54.

Williams, C. F., and R. P. Guries. 1994. Genetic consequences of seed dispersal in three sympatric forest herbs. I. Hierarchical population genetic structure. Evolution 48:791-805.

Wilson, A. C., R. L. Cann, S. M. Carr, M. George, U. B. Gyllensten, K. M. Helm-Bychowski, R. G. Higuchi, et al. 1985. Mitochondrial DNA and two perspectives on evolutionary genetics. Biological Journal of the Linnean Society 26:375-400.

Wood, T. K., and S. l. Guttman. 1982. Ecological and behavioral basis for reproductive isolation in the sympatric Enchenopa binotata complex (Homoptera: Membracidae). Evolution 36:233-242.

Wright, S. 1943. Isolation by distance. Genetics 28:139156.

1946. Isolation by distance under diverse systems of mating. Genetics 31:39-59.

. 1951. The genetical structure of populations. Annals of Eugenics 15:323-354.

Young, A., T. Boyle, and T. Brown. 1996. The population genetic consequences of habitat fragmentation for plants. Trends in Ecology \& Evolution 11:413-418.

Zera, A. J. 1981. Genetic structure of two species of waterstriders (Gerridae: Hemiptera) with differing degrees of winglessness. Evolution 35:218-225.

Associate Editor: Dolph Schluter 